\title{
Recent marine Ostracoda from the Solomon Islands: part 1 - Cypridoidea, Platycopina and Cladocopina
}

\author{
ROSEMARY TITTERTON ${ }^{1} \&$ ROBIN C. WHATLEY ${ }^{2}$ \\ ${ }^{1}$ Statoil, N-4035, Stavanger, Norway \\ ${ }^{2}$ Institute of Geography \& Earth Sciences, University of Wales, Aberystwyth, UK
}

\begin{abstract}
Sixteen species of marine Cypridoidea belonging to seven genera and a rather small fauna of nine platycopid and two cladocopid species from the Solomon Islands are described. Nine species are described and illustrated as new. They are: Paracypris contracta, Triangulocypris teeteri, T. umbonata, Aglaiocypris supercylindrica, Argilloecia teres, Propontocypris paracrocata, P. supertrigonella, Cytherelloidea asymmetrica and $C$. dictyotos ssp. nov. Five species have been described previously and 11 species are retained in open nomenclature. While the Cypridoidea comprise only $15 \%$ of the total fauna of 160 species recorded from the Solomon Islands, they are not insignificant and, in some environments, are among the dominant ostracods. The platycopids/cladocopids comprise only $13 \%$ of the total fauna but likewise are dominant in some environments. They are typically SW Pacific in character. J. Micropalaeontol. 25(1): 73-94, April 2006.
\end{abstract}

KEYWORDS: Solomon Islands, Recent marine Ostracoda, Cypridoidea, Platycopina, Cladocopina

\section{INTRODUCTION}

The present work is part of a larger study of the Quaternary and Recent Ostracoda of the Solomon Islands. Apart from Harding's (1962) study of species recovered from the gut of freshwater fishes, and two papers by the present authors on marine taxa (Whatley \& Titterton 1981; Titterton \& Whatley 1988), which dealt with two trachyleberidid genera and the large fauna (21 species) of Bairdiinae, respectively, the Ostracoda of the Solomon Islands have been sadly neglected. This is one of a series of publications to redress this situation. The first in this series is a paper on the Xestoleberididae (Titterton \& Whatley, 2005).

The Solomon Islands are situated to the NE of Australia and to the SE of New Guinea between Latitude $5-12^{\circ} \mathrm{S}$ and Longitude $155-162^{\circ} \mathrm{E}$ and enjoy an oceanic tropical climate. The samples on which this study is based were collected off the islands of Guadalcanal and Shortland (Fig. 1). The location of the samples is given in Figures 2 and 3. All of the samples are of largely biodetrital sand, ranging from very fine to medium in grain size. Much of the medium sand originated from coral and

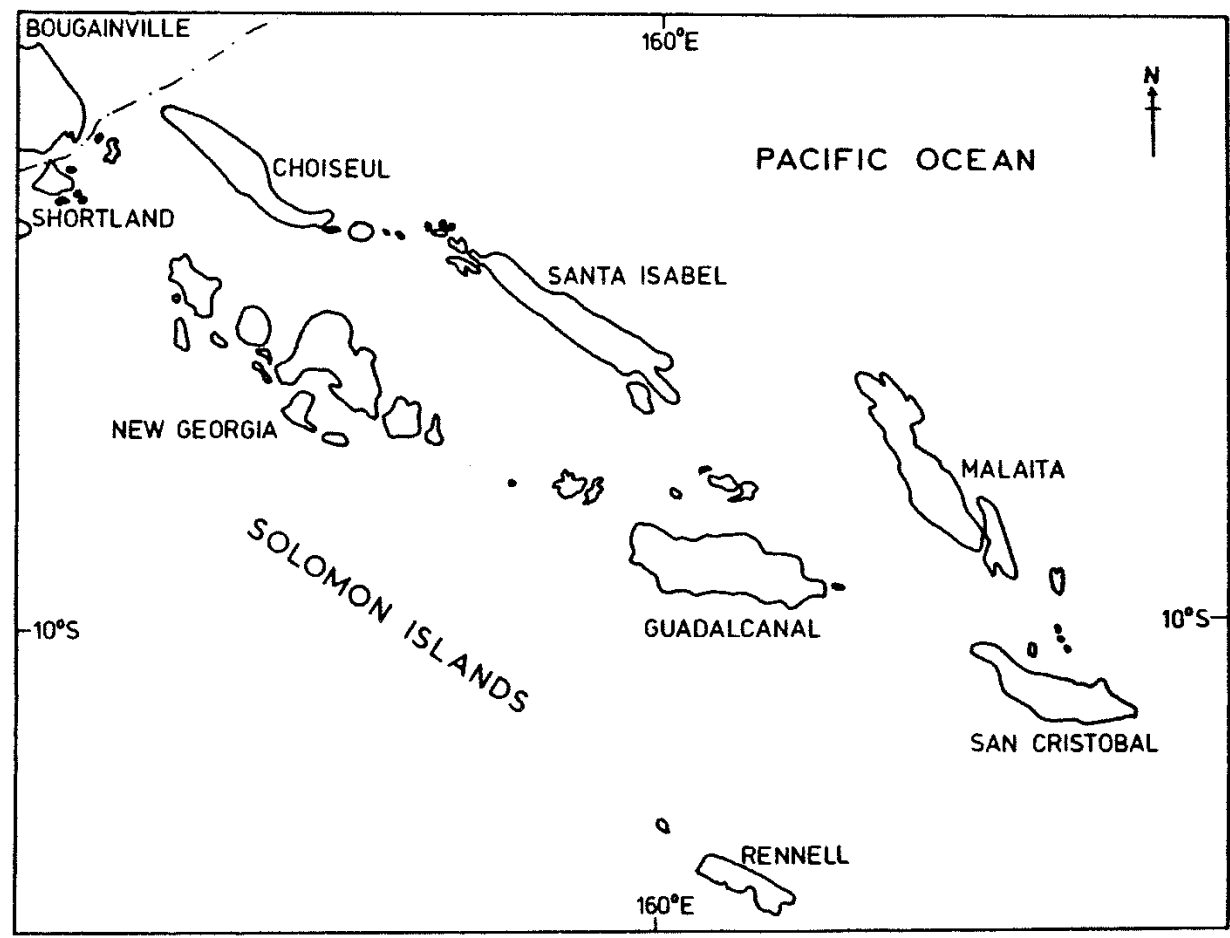

Fig. 1. The Solomon Islands. 


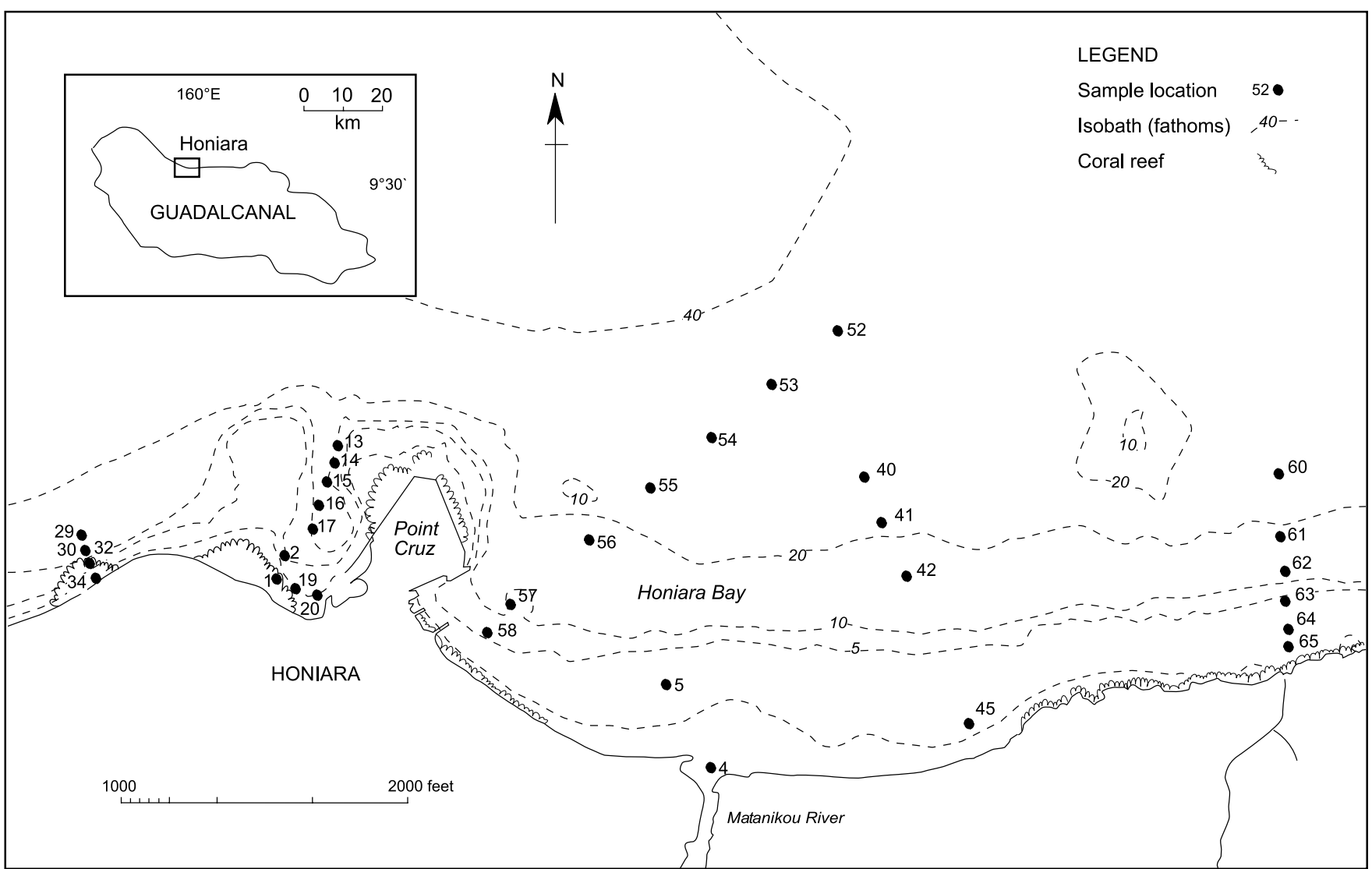

Fig. 2. Location of sample stations, Honiara Bay, N. Guadalcanal, Solomon Islands.

was collected with a simple pipe dredge or by diving. Details of the individual samples can be found in Titterton (1984) and Titterton \& Whatley (1988).

The total ostracod fauna comprises some 160 species belonging to 56 genera. The overwhelmingly dominant group is the Cytheroidea $(63 \%)$, the remainder are cyprids $(15 \%)$, bairdiids $(8 \%)$ and platycopids/cladocopids $(13 \%)$.

There has been a resurgence of studies of Ostracoda in the SW Pacific area. Among the important contributions of the last decades are Behrens (1991a, b - Great Barrier Reef), Cabioch et al. (1986 - New Caledonia), Dewi (1997 - Java Sea), Howe \& McKenzie (1989 - NW Australia), Jellinek (1993 - Kenya), Mostafawi (1992 - Malaysia), Whatley et al. (1995, 1996 Northern Australia; 2000 - Easter Island, Whatley \& Keeler (1989 - Reunion Island), Whatley \& Zhao (1987, 1988 Malacca Straits), Whatley \& Roberts (1995 - Pitcairn Group), Yassini et al. (1993 - Eastern Australia), Yassini \& Jones (1995 - Southern Australia), Zhao \& Whatley (1989 - Malaysia).

\section{SYSTEMATIC DESCRIPTIONS}

All the material is housed in the collections of the Natural History Museum, London. The type specimens of all new taxa and the majority of the figured specimens have catalogue numbers between OS 16155 and OS 16243. Other catalogue numbers prefixed RT/SIR refer to the Aberystwyth Collections, also housed in the Natural History Museum. In all cases, specimens are of adults unless otherwise stated. All dimensions are given in millimetres, and the size convention for adults is as follows: $<0.40$ very small, $0.40-0.50$ small, $0.50-0.70$ medium, 0.70-1.00 large, $>1.0$ very large. Other conventions used throughout are: $\mathrm{LV}$, left valve; $\mathrm{RV}$, right valve; $\mathrm{C}$, carapace; $\mathrm{A}$, adult; rpc, radial pore canal; npc, normal pore canal. All new taxa are described fully.

Order Podocopida Müller, 1894

Suborder Podocopina Sars, 1886

Superfamily Cypridoidea Baird, 1845

Family Macrocyprididae Müller, 1912

Genus Macrocyprina Triebel 1960

Macrocyprina maculata (Brady 1866)

(Fig. 4, nos 3, 7; Pl. 1, fig. 2)

1866 Cytherideis (Cytherideis) maculata Brady: 367, pl. 57, fig. $12 \mathrm{a}-\mathrm{b}$.

2001 Macrocyprina maculata (Brady); Titterton et al.: 34, pl. 1, figs $15-17$ (q.v. for synonymy).

In press Macrocyprina maculata (Brady); Whatley, Jones \& Roberts: pl. 2, figs 21, 22.

Type species. Macrocyprina propinqua Triebel, 1960.

Material. Four adult and 14 juvenile valves to A-3 instar. Samples 14, 15, 29, 40, 41, 52-56, OS6 Guadalcanal and Shortland islands. 


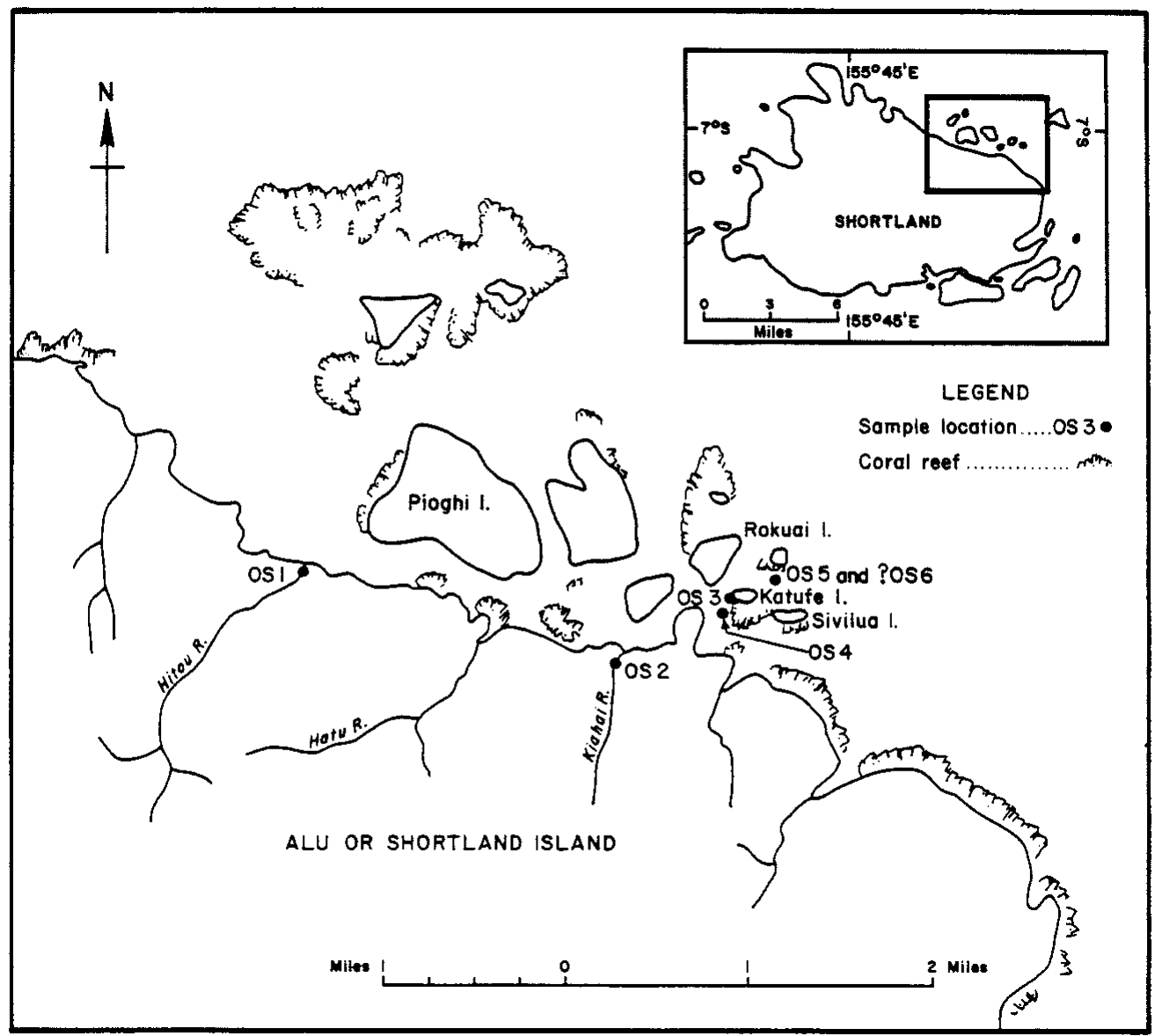

Fig. 3. Location of sample stations, Shortland Island, Solomon Islands.

\section{Dimensions.}

Female RV, OS 16161

A-1 LV, OS 16157

A-1 RV, RT/SIR/142

A-2 LV

A-3 LV

Mean dimensions.
5 A-1
$1.00(0.98-1.02)$
$0.80(0.75-0.86)$
$0.38(0.36-0.42)$
$0.29(0.27-0.31)$

Occurrence. Brady (1880) recorded this species from depths of 15-150 fathoms from Simon's Bay, South Africa; Kerguelen Island and Prince Edward Is., southern Indian Ocean; off East Mancoer Island, Bass Strait and off Amboyna in the South China Sea. It is doubtful whether the same species was recorded at all these stations (Watson, 1988; pers. comm.). Brady originally recorded the species from Western Australia and the West Indies (Turks Island). It also occurs in Quaternary (Williams, 1980) sediments from the Solomon Islands and around Pulau Seribu, in the Java Sea (Watson, 1988).

Remarks. The present species is most similar in shape to $M$. decora (Brady, 1866) but differs in that the dorsal margin is less arched and the posterodorsal margin is almost straight; in $M$. decora the posterodorsal margin is gently concave. The type material of $M$. decora is $>1.2 \mathrm{~mm}$ in length and is opaque (Watson's thesis material from the Java Sea has opaque patches), while the type material of $M$. maculata is $<1.0 \mathrm{~mm}$ and possesses opaque patches (Titterton et al., 2001).

\section{Family Pontocyprididae Müller, 1894}

Genus Pontocypris Sars, 1866

Pontocypris attenuata Brady, 1868

(Fig. 4, nos 9, 12; Pl. 2, figs 1-6)

1868 Pontocypris attenuata Brady: 179, pl. 4, figs 11-14.

1880 Pontocypris attenuata Brady; Brady: 38, pl. 15, fig. 2a-d. 2001 Pontocypris attenuata (Brady); Titterton et al., 35, pl. 1, figs 18-22 (q.v. for synonymy).

Type species. Cythere (Bairdia) mytiloides Norman, 1862 (=Cythere avena Norman, 1865; Pontocypris serrulata Sars, 1866; Erythrocypris serrata G. W. Muller, 1894) designated by Brady \& Norman, 1889.

Material. Six adults and 22 juveniles to A-3. Samples: 14, 15, 17 , 29, 41, 53, 55, 56, 58, 61 Guadalcanal. 

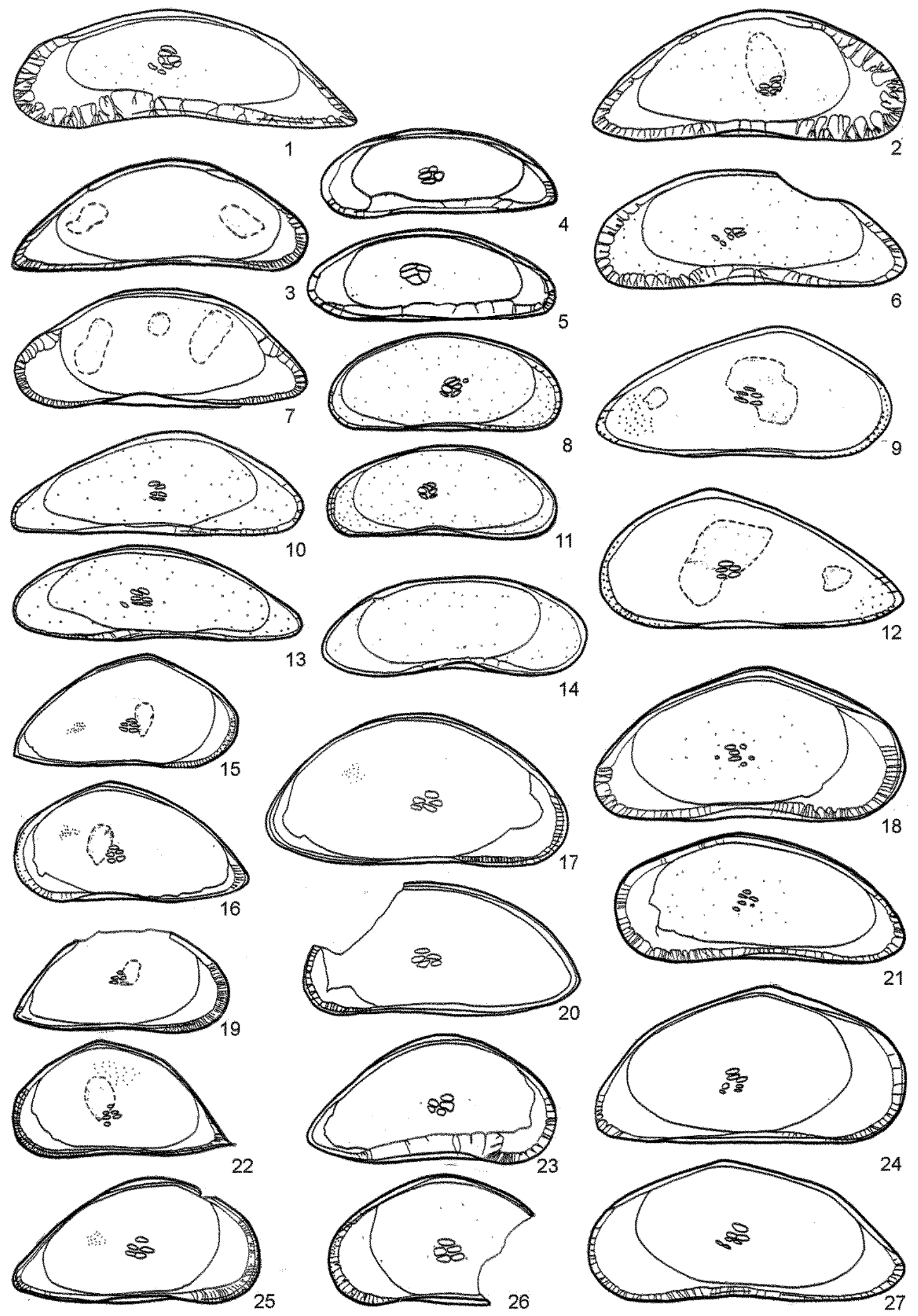


\begin{tabular}{llll} 
Dimensions. & Length & Height & Width \\
LV, OS 16197 & 0.77 & 0.36 & \\
C, OS 16163 & 0.75 & 0.37 & 0.28 \\
RV, OS 16196 & 0.74 & 0.36 & \\
RV, OS 16166 & 0.73 & 0.36 & \\
Mean dimensions. & & \\
2 A-1 C & $0.66,0.65$ & $0.32,0.33$ & $0.23,0.24$ \\
5 A-2 C & 0.56 & 0.27 & 0.29 \\
\multicolumn{5}{l}{ 7 A-2 } & $(0.54-0.58)$ & $(0.26-0.28)$ & $(0.27-0.31)$ \\
& 0.55 & 0.26 & \\
5 A-3 & $(0.53-0.56)$ & $(0.25-0.27)$ &
\end{tabular}

Occurrence. Pontocypris attenuata occurs widely in shallowwater assemblages of the Indo-Pacific, from Mauritius in the west to Japan in the north and off southeastern Australia, Funafuti and the Solomon Islands. NHM slide no. 80.38.6, Hong Kong Harbour, 7 fathoms (Brady 1880) contains some juveniles and NHM slide no. 12.4.64, Humbolt Bay, Papua, 37 fathoms, contains adults of this species. Fossil material is recorded in the Batesford Limestone (Chapman, 1910), the Tertiary of the Sorento borehole, Victoria, Australia (Chapman $\&$ Crespin, 1928) and Miocene of the Yatsuo Formation, Japan (Ishizaki, 1963).

Remarks. Maddocks, in her review of the Pontocyprididae (1990, table 1: 311) seems to include this species in Propontocypris Sylvester-Bradley, 1947. She then lists (1990: 328.) 'Propontocypris (Propontocypris) attenuata (Brady, 1868) of Okubo (1979)' among the species included within Propontocypris by original binomen. However, since she does not seem to mention Pontocypris attenuata Brady, 1868 elsewhere, it is possible that she may have overlooked this species in her review.

Pontocypris sp. A

(P1. 2, fig. 7)

Material. Two juvenile valves. Samples 14, 57 Guadalcanal.

\section{Dimensions.}

$\begin{array}{lll} & \text { Length } & \text { Height } \\ \text { Juvenile RV, OS } 16198 & 0.61 & 0.29 \\ \text { Juvenile LV } & 0.50 & 0.25\end{array}$

Remarks. These two densely micropunctate juvenile valves could not be assigned to any known species.

Family Paracyprididae Sars, 1923

Genus Paracypris Sars, 1866
Paracypris bradyi McKenzie, 1967

(Fig. 4, nos 2, 6; Pl. 1, figs 9, 12-13)

1967 Paracypris bradyi McKenzie: 64, fig. 2d.

1981 Paracypris bradyi McKenzie; Hartmann: 128

Type species. Paracypris polita Sars, 1866.

Material. Seven adult valves, one adult carapace and one A-1 juvenile valve. Samples 14, OS3, OS6 Guadalcanal and Shortland islands.

Occurrence. Swash mark, Port Phillip Bay, Victoria and in a tidal pool at Seaholme, Victoria (McKenzie, 1967). Littoral sediments, Brisbane, Northwestern Australia (Hartmann, 1981).

\section{Dimensions.}

LV, OS 16187

RV, OS 16160

LV, OS 16156

A-1 LV
Length

0.77

0.77

0.79

0.61
Height

0.30

0.31

0.31

0.22
Remarks. Although McKenzie's (1967) original material seems to have rather fewer radial pore canals, as do Hartmann's (1981) specimens from Brisbane, the authors are confident that the material from the Solomon Island is conspecific. Paracypris polita Sars, 1866 (Recent, Norway) is similar in shape but slightly more acuminate posteriorly and is larger $(1.23 \mathrm{~mm}$ in length) and has less complex rpcs. Paracypris pacificus LeRoy, 1943, from the Pliocene-Pleistocene of Southern California, is larger $(1.10 \mathrm{~mm}$ in length) than the present species, and the posterior margin is more acuminate and slightly upturned.

Paracypris contracta sp. nov.

(Fig. 4, nos 10, 13; Pl. 1, figs 3-7)

Derivation of name. $L$; with reference to the narrowness of the carapace in dorsal view.

Diagnosis. Elongate sub-triangular shape in lateral view and elongate, narrow diamond shape in dorsal view; anterior narrowly rounded. Large semicircular anterior and posterior vestibulae. Rpcs moderately numerous, short, simple, straight.

Holotype. LV, OS 16182.

Paratypes. C, OS 16185; RV, OS 16183; LV, OS 16164.

\footnotetext{
Fig. 4. Internal lateral views, Cypridoidea. 1. Paracypris sp. A, RV, OS $16155 \times 62.1$. 2, 6. Paracypris bradyi McKenzie, 1967: 2, LV, OS 16156 $\times 65.9 ; 6$, RV, OS $16160 \times 67.4$. 3, 7. Macrocyprina maculata (Brady, 1866): 3, A-1 LV, OS $16157 \times 50.5 ;$ 7, RV, OS 16161 × 41.4. 4, 5. Argilloecia sp. A: 4, RV, OS $16158 \times 96.3 ; \mathbf{5}$, RV, OS $16159 \times 98.1$. 8, 11. Aglaiocypris supercylindrica sp. nov.: 8, Paratype LV, OS 16162 × 63.9; 11, RV, OS $16165 \times 68.0 .9$, 12. Pontocypris attenuata Brady, 1868: 9, LV, OS $16163 \times 63.5 ; 12$, RV, OS $16166 \times 69.7$. 10, 13. Paracypris contracta sp. nov.: 10, Paratype LV, OS $16164 \times 66.8 ; 13$, RV, OS $16167 \times 64.3$. 14. Argilloecia teres sp. nov., Holotype LV, OS $16168 \times 65.4$. 15, 16. Propontocypris paracrocata sp. nov.: 15, Holotype LV, OS $16169 \times 39.9$; 16, Paratype RV, OS $16170 \times 42.0 .17$, 20. Propontocypris sp. C: 17, LV, OS $16171 \times 67.8$; 20, RV, OS $16174 \times 67.9 .18,21$. Triangulocypris teeteri $\mathrm{sp}$. nov.: 18, Paratype LV, OS $16172 \times 66.4 ; \mathbf{2 1}$, RV, OS $16175 \times 65.1 .19,22$. Propontocypris sp. A: 19, LV, OS $16173 \times 39.2 ;$ 22, RV, OS $16176 \times 38.9$. 23, 26. Propontocypris sp. B: 23, LV, OS $16177 \times 66.9 ; 26$, RV, OS $16180 \times 66.3 .24,27$. Triangulocypris umbonata sp. nov.: 24, Paratype LV, OS $16178 \times 61.8 ; 27, \mathrm{RV}$, OS $16181 \times 66.3$. 25. Propontocypris supertrigonella sp. nov., Paratype LV, OS $16179 \times 63.5$.
} 


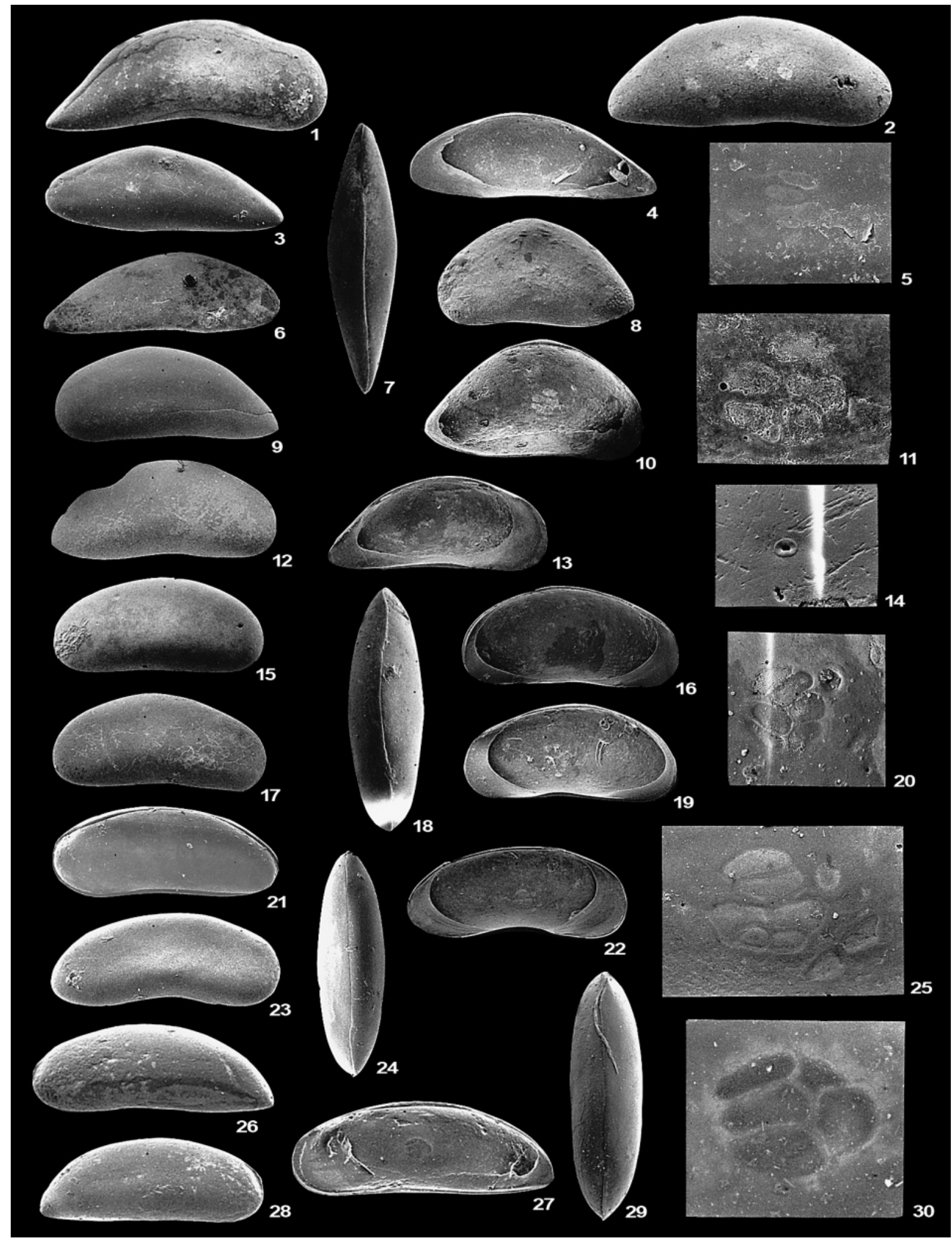


Material. 36 valves and carapaces, A-4 to adult. Samples 2, 17, OS6 Guadalcanal and Shortland islands.

Locality and horizon. Sample 17, 850 feet offshore west of Point Cruz, Honiara Bay, Guadalcanal. 10 fathoms. Unconsolidated, medium-grained coral sand. Recent.

Description. Large. Moderately thin-shelled. Translucent. Elongate, sub-rectangular in shape in lateral view: elongate, narrow diamond shape in dorsal view. Anterior margin narrow, well rounded: extremity well below mid-height. Posterior margin strongly acuminate, sharply rounded and with sub-ventral apex. Dorsal margin very strongly arched, more angularly so in LV: cardinal angles rounded. Ventral margin almost straight. Greatest length sub-ventral; greatest height and width just anterior to mid-length. LV $>\mathrm{RV}$ with slight overlap dorsomedianly and in oral region. Surface of valves smooth. Npcs numerous, large, regularly distributed. Inner lamella wide; large semicircular anterior and posterior vestibulae except in oral region where the narrow fused zone of the inner lamella is broadest. Rpcs moderately numerous, approximately 22 anterior and six posterior canals, short, simple, straight. Hinge adont. Central muscle scars a cluster of six; two obliquely aligned dorsal scars and four ventral scars in a double row.

$\begin{array}{llll}\text { Dimensions. } & \text { Length } & \text { Height } & \text { Width } \\ & & & \\ \text { Holotype LV, OS 16182 } & 0.76 & 0.28 & \\ \text { Paratype C, OS 16185 } & 0.81 & 0.28 & 0.19 \\ \text { RV, OS 16184 } & 0.72 & 0.24 & \\ \text { Paratype RV, OS 16183 } & 0.76 & 0.25 & \\ \text { Paratype LV, OS 16164 } & 0.73 & 0.26 & \\ \text { RV, OS 16167 } & 0.75 & 0.25 & \\ \text { A-1 C } & 0.65 & 0.22 & 0.12 \\ \text { A-1 LV } & 0.65 & 0.22 & \\ \text { A-2 RV } & 0.52 & 0.19 & \\ \text { A-3 C } & 0.43 & 0.15 & 0.12 \\ \text { A-4 C } & 0.35 & 0.14 & 0.11 \\ \text { Mean dimensions. } & & & \\ \text { 13 C } & 0.75 & 0.27 & 0.20 \\ & (0.71-0.80) & (0.25-0.28) & (0.19-0.21) \\ \text { 9 LV } & 0.74 & 0.26 & \\ & (0.72-0.77) & (0.25-0.28) & \\ \text { 4 RV } & 0.52 & 0.24 & \\ & (0.72-0.75) & (0.25-0.25) & \end{array}$

Remarks. The present species has been placed in Paracypris on the basis of its shape and muscle scar pattern, which is typical for that genus. The fused zone of the inner lamella, however, is narrow and the marginal pore canals correspondingly short and simple. The narrow anterior margin and the elongate, narrow diamond shape of the carapace in dorsal view distinguish the present species. Pontocypris gracilis Brady, 1890 is similar in lateral outline to $P$. contracta but is larger (1.07 $\mathrm{mm}$ in length), and is regularly inflated in dorsal view. Paracypris sp. A of Whatley et al. (1996) from the Recent of Port Darwin is much more ventrally acuminate than any of the species encountered in this study.

\section{Paracypris sp. A}

(Fig. 4, no. 1; Pl. 1, fig. 1)

Material. One adult right valve and four juvenile valves to A-3 instar.

$\begin{array}{lll}\text { Dimensions. } & & \\ & \text { Length } & \text { Height } \\ \text { RV, OS 16155 } & 0.92 & 0.35 \\ \text { A-1 LV } & 0.80 & 0.30 \\ \text { A-1 LV } & 0.81 & 0.31 \\ \text { A-2 LV } & 0.67 & 0.26 \\ \text { A-3 LV } & 0.54 & 0.22\end{array}$

Remarks. The present species is very similar in shape to several fossil species of the genus, for example $P$. wrothamensis Kaye, 1965 from the Albian of Britain and P. parapiculata Alexander, 1934 from the Eocene of Texas. No species described from the Recent of the Pacific Ocean is so strongly acumimate posteriorly or concave ventrally except $P$. franquesi Howe \& Chambers, 1935 of Holden, 1976 (Miocene-Pleistocene of Midway Island). This species, however, is smaller $(0.77 \mathrm{~mm}$ in length $)$ and of a different shape dorsally than the present species. The species described above is probably new but is left in open nomenclature due to its rarity.

\section{Genus Triangulocypris Teeter, 1975}

Triangulocypris teeteri $\mathrm{sp}$. nov. (Fig. 4, nos 18, 21; Pl. 2, figs 25-28)

Type species. Triangulocypris laeva (Puri), 1960.

Derivation of name. $L$; named for the author of the genus.

Diagnosis. A sub-triangular species of Triangulocypris with numerous, extremely minute striations on the carapace but most

\section{Explanation of Plate 1.}

fig. 1. Paracypris sp. A, RV, OS 16155 external lateral view $\times 53.8$. fig. 2. Macrocyprina maculata (Brady, 1866). RV, OS 16161 external lateral view $\times$ 41.9. figs 3-7. Paracypris contracta sp. nov.: 3, Holotype LV, OS 16182 external lateral view $\times 55.3 ;$ 4, 5, Paratype LV, OS $16183-(4)$ internal view $\times 56.7$, (5) detail of central muscle scar $\times 215.6 ; \mathbf{6}, \mathrm{RV}$, OS 16184 external lateral view, $\times 57.2 ; 7$, Paratype C, OS 16185 dorsal view $\times 63.7$. figs 8, 10-11. Propontocypris sp. B: 8, LV, OS 16186 external lateral view $\times 59.4 .3 ; \mathbf{1 0}, \mathbf{1 1}, \mathrm{LV}$, OS $16177-(\mathbf{1 0})$ internal view $\times 64.5,(\mathbf{1 1})$ detail of central muscle scar $\times$ 984.4. figs 9, 12-13. Paracypris bradyi McKenzie, 1967: 9, LV, OS 16187 external lateral view $\times 50.8$; 12, RV, OS 16160 external lateral view, $\times 51.8 ; \mathbf{1 3}$, LV, OS 16156 internal view, $\times 48.4$. figs 14-20. Aglaiocypris supercylindrica sp. nov.: 14, 17, Paratype LV, OS 16188 - (14) detail of normal pore canal $\times 894.9$, (17) external lateral view $\times 61.0 ; 15$, Holotype LV, OS 16189 , external lateral view $\times 63.0$; 16, 20, Paratype LV, OS $16162-(\mathbf{1 6})$ internal view, $\times 62.3$, (20) detail of central muscle scar $\times 274.7$; 18, Paratype C, OS 16190 dorsal view $\times 75.0 ; 19$, RV, OS 16165 internal view $\times 66.3$. figs 21-25. Argilloecia teres sp. nov.: 21, 24, Paratype C, OS $16191-(\mathbf{2 1})$ external lateral view of left valve $\times 57.4$, (24) dorsal view $\times 56.0$; 22, 25, Holotype LV, OS $16168-(\mathbf{2 2})$ internal view $\times 54.7$, (25) detail of central muscle scar $\times 374.6$; 23, Paratype RV, OS 16192 external lateral view $\times 60.6$. figs 26-30. Argilloecia sp. A: 26, LV, OS 16194 external lateral view $\times 105.3 ; \mathbf{2 7}, \mathbf{3 0}$, RV, OS 16159-(27) internal view $\times 109.5$, (30) detail of central muscle scar $\times 273.3 ; \mathbf{2 8}$, RV, OS 16158 external lateral view $\times 95.1 ; 29$, C, OS 16195 dorsal view $\times 102.3$. 


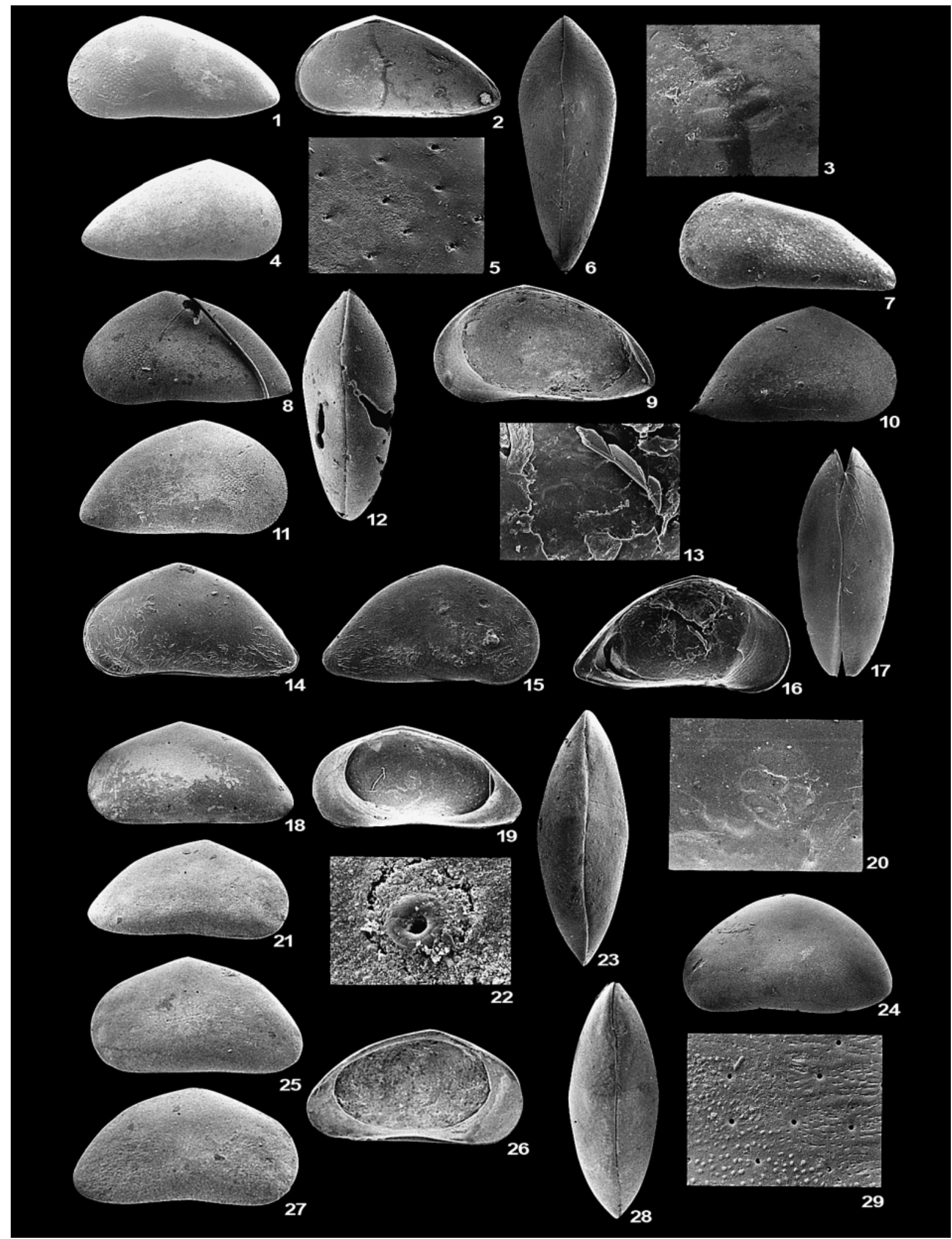


prominent postero-laterally and with a sub-rounded posterior margin in the left valve.

Holotype. LV, OS 16209.

Paratypes. LV, OS 16172; C, OS 16210; LV, OS 16208.

Locality and horizon. Sample 0S6, exact location unknown but thought to be from the intertidal zone, near a coral reef, off the northeast coast of Shortland Island, in the vicinity of Rokuai Island. Coarse-grained coral sand. Recent.

Material. 350 valves and carapaces, A-3 to adult. Samples 2, 5, 14, 17, 56, OS6 Guadalcanal and Shortland islands.

Description. Large. Rather thick-shelled. Live specimens light brown, otherwise translucent with cloudy central opaque area or white opaque. Sub-triangular in lateral view: sub-elliptical in dorsal view. Anterior margin well rounded but with marked anterodorsal angle. Posterior margin sub-rounded in LV, slightly more pointed in RV; apex sub-ventral. Dorsal margin angularly arched. Ventral margin with median oral incurvature, especially in RV. Surface of valves under low power appears smooth and shiny, but higher power observation reveals that it is covered with horizontally disposed extremely small and shallow striae. Although observable with the light microscope, most clearly on the strongly reflecting parts of the surface under incident light, they are difficult to see under the SEM. Inner lamella very wide; large crescentic vestibulae at each end; fused zone narrow with more than 40 short simple, slightly sinuous rpcs anteriorly and 30 posteriorly. Hinge adont but robust. Central muscle scars always indistinct but comprising six subovate scars; one dorsal scar, three in a vertical row anteriorly and two posteriorly; possibly a seventh scar posteroventrally.

$\begin{array}{llll}\text { Dimensions. } & \text { Length } & \text { Height } & \text { Width } \\ \text { Holotype LV, OS 16209 } & 0.73 & 0.37 & \\ \text { Paratype LV, OS 16208 } & 0.76 & 0.39 & \\ \text { RV, OS 16175 } & 0.75 & 0.38 & \\ \text { Paratype C, OS 16210 } & 0.83 & 0.41 & 0.30 \\ \text { Paratype LV, OS 16172 } & 0.78 & 0.40 & \\ \text { Mean dimensions. } & & & \\ \text { 10 C } & 0.74 & 0.39 & \\ & (0.72-0.78) & (0.36-0.41) \\ 10 \text { RV } & 0.76 & 0.37 & \\ & (0.72-0.80) & (0.35-0.38)\end{array}$

$\begin{array}{llll}6 \text { A-1 C } & 0.67 & 0.32 & 0.23 \\ & (0.62-0.71) & (0.29-0.34) & (0.21-0.24) \\ 10 \text { A-1 LV } & 0.67 & 0.33 & \\ & (0.61-0.71) & (0.29-0.35) & \\ 10 \text { A-1 RV } & 0.67 & 0.32 & \\ & (0.62-0.71) & (0.29-0.34) & \\ 2 \text { A-2 C } & 0.56 & 0.26,0.27 & 0.19 \\ 4 \text { A-2 } & 0.54 & 0.27 & \\ & (0.53-0.54) & (0.26-0.27) & \\ 1 \text { A-3 } & 0.43 & 0.22 & \end{array}$

Remarks. This species differs from $T$. umbonata $\mathrm{sp}$. nov. by its smaller size, in being less acuminate posteriorly and in possessing minute striae on its lateral surface. Triangulocypris umbonata is completely smooth.

Triangulocypris umbonata $\mathrm{sp}$. nov.

(Fig. 4, nos 24, 27; Pl. 2, figs 18-23)

Derivation of name. $L$; with reference to the pointed, almost umbonate, central part of the dorsal margin.

Diagnosis. An elongate, sub-umbonate species of Triangulocypris, sub-triangular in lateral view and with pronounced but very obtuse posterior cardinal angles.

Holotype. LV, OS 16204.

Paratypes. C, OS 16207; LV, OS 16178; RV, OS 16206.

Material. 63 valves and carapaces, A-3 to adult. Samples 1, 2, 5, 13, 14, 19, 29, 32, 40, 58, 6I, OS6 Guadalcanal and Shortland islands.

Locality and horizon. Sample 5, 800 feet offshore from the mouth of the Matanikau River, Honiara Bay, Guadalcanal. 3 fathoms. Medium-grained sand. Recent.

Description. Large, rather thin-shelled. Translucent or slightly brown in colour. Elongate, sub-triangular in lateral view: elliptical in dorsal. Anterior margin broadly rounded, particularly in LV, extremity at mid-height. Posterior margin bluntly pointed with sub-ventral extremity. Dorsal margin straight and inclined towards the posterior with sub-/umbonate cardinal angle just anterior of mid-length and pronounced but very obtuse posterior cardinal angle. Ventral margin very shallowly biconvex about a medial incurvature. Valve surface smooth, npcs numerous, simple. Inner lamella broad, large semicircular

Explanation of Plate 2.

figs 1-6. Pontocypris attenuata Brady, 1868: 1, 5, LV, OS $16163-(\mathbf{1})$ external lateral view $\times 48.2$, (5) detail of normal pore canal $\times 875.5 ; \mathbf{2}, \mathbf{3}$, LV, OS 16166 - (2) internal view $\times 49.5$, (3) detail of central muscle scar $\times 245.3$; 4, RV, OS 16196 external lateral view $\times 47.4$; 6 , C, OS 16197 dorsal view $\times$ 45.8. fig. 7. Pontocypris sp. A, JLV, OS 16198 external lateral view $\times 62.3$. figs 8, 9, 11, 12. Propontocypris paracrocata sp. nov.: 8, Holotype LV, OS 16169 external lateral view $\times 39.4$; 9, Paratype RV, OS 16199 internal view $\times 42.4$; 11, Paratype RV, OS 16170 external lateral view $\times 38.6$; 12, Paratype C, OS 16200 dorsal view $\times 39.0$. fig. 10. Propontocypris sp. A: RV, OS 16176 external lateral view $\times 37.7$. figs 13-17. Propontocypris supertrigonella sp. nov.: 13, 16, Paratype RV, OS $16179-(\mathbf{1 3})$ detail of muscle scar $\times 231.0$, (16) internal view $\times 58.5$; 14, Paratype C, OS 16201 external lateral view of left valve $\times 57.2 ; \mathbf{1 5}$, Paratype C, OS 16202 external lateral view $\times 57.0 ; \mathbf{1 7}$, Holotype C, OS 16203 dorsal view $\times 57.0$. figs 18-23. Triangulocypris umbonata sp. nov.: 18, 22, Holotype LV, OS $16204-(\mathbf{1 8})$ external lateral view $\times 46.2$, (22) detail of normal pore canal $\times 2493.2 ; \mathbf{1 9}, \mathbf{2 0}, \mathrm{RV}$, OS $16205-(\mathbf{1 9})$ internal view $\times 45.4,(\mathbf{2 0})$ detail of muscle scar $\times 199.0 ; 21$, Paratype RV, OS 16206 external lateral view $\times$ 43.9; 23, Paratype C, OS 16207 dorsal view $\times 57.5$. figs 24, 29. Propontocypris sp. C, LV OS 16171: 24, external lateral view $\times 49.7$; 29, detail of lateral ornament $\times$ 984.4. figs 25-28. Triangulocypris teeteri sp. nov.: 25, LV, OS 16208 external lateral view $\times 51.3 ;$ 26, Holotype LV, OS 16209 internal view $\times 48.6$; 27, Paratype RV, OS $16175 \times 48.0$; 28, Paratype C, OS 16210 dorsal view $\times 48.3$. 
vestibulae at each end, fused zone very narrow. Rpcs short, straight and simple; 36 anteriorly and 16 posteriorly. Hinge adont. Central muscle scars a compact cluster of 6 scars.

$\begin{array}{llll}\text { Dimensions. } & \text { Length } & \text { Height } & \text { Width } \\ \text { Holotype LV, OS 16204 } & 0.78 & 0.39 & \\ \text { Paratype C, OS 16207 } & 0.78 & 0.39 & 0.28 \\ \text { Paratype RV, OS 16206 } & 0.80 & 0.38 & \\ \text { RV, OS 16205 } & 0.81 & 0.38 & \\ \text { Paratype LV, OS 16178 } & 0.84 & 0.43 & \\ \text { RV, OS 16181 } & 0.80 & 0.40 & \\ \text { Mean dimensions. } & & & \\ \text { 10 C } & 0.81 & 0.40 & 0.30 \\ & (0.78-0.84) & (0.35-0.44) & (0.28-0.31) \\ \text { 10 LV } & 0.81 & 0.41 & \\ & (0.78-0.84) & (0.39-0.43) & \\ \text { 10 RV } & 0.80 & 0.38 & \\ & (0.78-0.83) & (0.36-0.41) & \\ \text { 9 A-1 LV } & 0.66 & 0.33 & \\ & (0.64-0.69) & (0.31-0.35) & \\ \text { 9 A-1 RV } & 0.65 & 0.31 & \\ & (0.62-0.69) & (0.30-0.33) & \\ \text { 4 A-2 } & 0.51 & 0.25 & \\ & (0.43-0.53) & (0.24-0.26) & \\ \text { 1 A-3 } & 0.44 & 0.23 & \end{array}$

Occurrence. Quaternary marine sediments from offshore, Guadalcanal (Williams, 1980).

Remarks. This species differs from the type, T. laeva (Puri) from the Caribbean in its somewhat smaller size and more angular dorsal and posterior margins. Paracypris maryboroughensis Hartmann, 1981 from the Recent, eulittoral of eastern Australia probably belongs to Triangulocypris, although his drawings of the central muscle field shows only four adductor scars, possibly because the illustration is incomplete. Hartmann's species differs in being notably less acuminate posteriorly.

Genus Aglaiocypris Sylvester-Bradley, 1946

Aglaiocypris supercylindrica $\mathrm{sp}$. nov.

(Fig. 4, nos 8, 11; P1. 1, figs 14-20)

Type species. Aglaia pulchella Brady, 1868.

Derivation of name. $L$; with reference to the very cylindrical shape of the carapace in dorsal view.

Holotype. LV, OS 16189.

Paratypes. LV, OS 16162; RV, OS 16188; C, OS 16190.

Locality and horizon. Sample 0S6. Exact location unknown but thought to be from the intertidal zone, near a coral reef, off the northeast coast of Shortland Island in the vicinity of Rokuai Island. Recent.

Material. 21 valves and carapaces, A-2 to adult. Sample OS6 Shortland Island.
Diagnosis. A species of Aglaiocypris, elongate reniform in lateral view and cylindrical in dorsal; anterior and posterior margins of equal height. Approximately 21 short, simple rpcs anteriorly and six posteriorly. CMSs an ovate patch of six; two oblique scars dorsally and four ventral scars arranged in two vertical rows.

Description. Medium. Moderately thin shelled. Translucent. Elongate reniform in lateral view: cylindrical in dorsal view. Anterior and posterior broad, well rounded; extremity just below mid-height. Dorsal margin broadly convex; cardinal angles rounded. Ventral margin gently concave; broad oral concavity. Greatest length just below mid-height; greatest height and width median. LV > RV, greatest overlap at dorsal cardinal angles. Surface of valves smooth. Npcs numerous, densest anteriorly. Inner lamella well developed with narrow fused zone; broad semicircular anterior vestibule; narrow, crescentic posterior vestibule. Rpcs few; approximately 21 anterior and six posterior canals, short simple and straight. Hinge adont. Central muscle scars an ovate patch of six, two oblique dorsally and four ventrally in two vertical rows.

\section{Dimensions.}

$\begin{array}{llll} & \text { Length } & \text { Height } & \text { Width } \\ \text { Holotype LV, OS 16189 } & 0.57 & 0.24 & \\ \text { Paratype LV, OS 16162 } & 0.61 & 0.26 & \\ \text { Paratype RV, OS 16188 } & 0.61 & 0.25 & \\ \text { Paratype C, OS 16190 } & 0.61 & 0.25 & 0.18 \\ \text { RV, OS 16165 } & 0.56 & 0.23 & \\ \text { Mean dimensions. } & & & \\ \text { 3 C } & 0.60 & 0.25 & 0.18 \\ & (0.58-0.61) & (0.25-0.26) & (0.18-0.19) \\ \text { 3 LV } & 0.59 & 0.25 & \\ & (0.58-0.61) & (0.25-0.26) & \\ \text { 6 RV } & 0.58 & 0.25 & \\ & (0.56-0.60) & (0.24-0.25) & \\ \text { 1 A-1 LV } & 0.50 & 0.21 & \\ \text { 1 A-1 RV } & 0.52 & 0.22 & \\ \text { 1 A-2 } & 0.44 & 0.19 & \end{array}$

Remarks. Aglaia meridionalis Brady, 1880 from the Recent off Southeastern America, is similar in shape to the present species but the right valve is the larger. Maddocks (1968: 135) remarked on Brady's type material of $A$. meridionalis of which there was only one specimen. This was not the specimen that Brady (1880) had described as it was more elongate and the left valve was larger than the right valve. Maddocks (1968) placed this species in Pontocypria Muller, 1894. Aglaia pulchella Brady, 1868 (Recent, off Sicily) is also similar in shape to the present species but possesses a different muscle scar pattern. Aglaiocpris virgenensis Swain, 1967 (Recent, off California) differs slightly in shape and is smaller $(0.43 \mathrm{~mm}$ in length).

Genus Argilloecia Sars, 1866

Argilloecia teres sp. nov.

(Fig. 4, no. 14; P1. 1, figs 21-25)

Type species. Argilloecia cylindrica Sars, 1866. 
Derivation of name. $L$; with reference to the rounded posterior margin.

Holotype. LV, OS 16168.

Paratypes. C, OS 16191; C, OS 16193; RV, OS 16192.

Locality and horizon. Sample 20, 100 feet offshore, west of Point Cruz, Honiara Bay, Guadalcanal. 2 fathoms. Unconsolidated, medium-grained coral sand. Recent.

Material. Nine adult valves and carapaces. Sample 20 Guadalcanal.

Diagnosis. Elongate, reniform in lateral view, both anterior and posterior margins well rounded. Fused zone narrow, widest ventrally. Central muscle scars an ovate group of six elongate scars, two dorsal in a vertical row and four ventral in two horizontal rows.

Description. Medium. Moderately thin shelled. Translucent. Elongate, reniform in lateral view, elliptical in dorsal. Anterior well rounded; extremity about mid-height. Posterior slightly narrower, more rounded: extremity well below mid-height. Dorsal margin broadly convex, cardinal angles rounded. Ventrally biconvex; strong, broad oral concavity. Maximum length well below mid-height; maximum height and width median. Surface of valves smooth. Npcs small, numerous. Inner lamella wide, narrow ventrally; fused zone narrow, widest ventrally. Well-developed crescentic vestibulae. A few, simple, straight rpcs orally. Hinge adont. Central muscle scars an ovate group of six elongate scars, two dorsally in a vertical row and four ventrally in two horizontal rows; two elongate frontal scars in oblique row. Ovate fulcral point just anterior to two dorsal scars.

Dimensions.

$\begin{array}{llll} & \text { Length } & \text { Height } & \text { Width } \\ \text { Holotype LV, OS 16168 } & 0.68 & 0.24 & \\ \text { Paratype C, OS 16191 } & 0.68 & 0.25 & 0.20 \\ \text { Paratype RV, OS 16192 } & 0.66 & 0.23 & \\ \text { Paratype C, OS 16193 } & 0.67 & 0.24 & 0.20 \\ \text { C } & 0.66 & 0.24 & 0.19\end{array}$

Remarks. Argilloecia sp. 2 of Maddocks, 1969, from the Recent of the Bay of Bengal is similar in shape but is more acuminate posteriorly, the extremity of the posterior margin is more ventral and the muscle scar pattern is typical of the genus, consisting of five scars. Argilloecia eburnea Brady, 1880 from the Recent off Kerguelen Island, is more acuminate posteriorly than the present species.

$$
\text { Argilloecia sp. A }
$$

(Fig. 4, nos 4, 5; P1. 1, figs 26-30)

Material. Seven adult valves. Samples 54-56, 60 Guadalcanal.

\section{Dimensions.}

$\begin{array}{llll} & \text { Length } & \text { Height } & \text { Width } \\ \text { C, OS 16195 } & 0.42 & 0.15 & 0.13 \\ \text { LV, OS 16194 } & 0.40 & 0.14 & \\ \text { RV, OS 16158 } & 0.41 & 0.15 & \\ \text { RV, OS 16159 } & 0.42 & 0.16 & \\ \text { C } & 0.43 & 0.15 & 0.13 \\ \text { C } & 0.43 & 0.16 & 0.14\end{array}$

Remarks. This species is characterized by its very sub-cylindrical shape in dorsal aspect and by its rounded anterior and subventrally acuminate posterior margin. It belongs to that group of Argilloecia species in which the fused zone of the inner lamella is narrow except ventrally. Argilloecia sp. 2 of Maddocks, 1969 (Recent, Bay of Bengal) is similar in shape but has a narrow fused zone ventrally. Another species that is similar in shape is Argilloecia affinis Brady, 1911 (Recent, Madeira) but it is longer $(0.54 \mathrm{~mm})$ and proportionally higher.

Genus Propontocypris Sylvester-Bradley, 1947

Propontocypris paracrocata $\mathrm{sp}$. nov. (Fig. 4, nos 15, 16; Pl. 2, figs 8-9, 11-12)

Type species. Pontocypris trigonella Sars, 1866.

Derivation of name. $L$; with reference to the similarity in overall morphology of this species to Propontocypris crocata Maddocks, 1969, from the Recent of Madagascar.

Holotype. LV, OS 16169.

Paratypes. C, OS 16200; RV, OS 16199; RV, OS 16170.

Locality and horizon. Sample 14, 1400 feet offshore, west of Point Cruz, Honiara Bay, Guadalcanal. 10 fathoms. Unconsolidated, medium-grained coral sand. Recent.

Material. 59 valves and carapaces, A-4 to adult. Samples 1, 13-17, 53, 55-58 Guadalcanal.

Diagnosis. A large species of Propontocypris, sub-triangular in lateral view, hastate in dorsal view. Anterior well rounded: posterior acuminate with short posterior spine in juveniles (may be broken in adults). Translucent with small, sub-central opaque patch. Fused zone of inner lamella narrow, broad, crescentic vestibulae.

Description. Large. Moderately thin shelled. Translucent with small, sub-central opaque patch. Sub-triangular in lateral view: hastate in dorsal view. Anterior well rounded: extremity at about mid-height. Posterior acuminate, sharply pointed: extremity sub-ventral. (Short, strong pointed spine at extremity in both valves of juveniles, may be broken in adults.) Dorsal margin angularly convex, angle just anterior to mid-length, posterior cardinal angle rounded. Ventral margin very gently concave. Maximum length sub-ventral, maximum height through dorsal angle, maximum width median. Valves surface smooth to minutely punctate. Npcs extremely numerous, small, 
simple. Inner lamella moderately wide, fused zone narrow, broad crescentic vestibulae. Rpcs false, appear as pore openings around margin, a double row of about 26-30 pores anteriorly, posterior pores unclear. Hinge adont. Central muscle scars a rosette of five elongate scars with one dorsally and four ventrally in two horizontal rows.

Dimensions.

$\begin{array}{llll} & \text { Length } & \text { Height } & \text { Width } \\ \text { Holotype LV, OS 16169 } & 0.94 & 0.49 & \\ \text { Paratype C, OS 16200 } & 0.93 & 0.49 & 0.37 \\ \text { Paratype RV, OS 16170 } & 0.94 & 0.50 & \\ \text { Paratype RV, OS 16199 } & 0.92 & 0.47 & \\ \text { LV } & 0.90 & 0.48 & \\ \text { Mean dimensions. } & & & \\ \text { 4 RV } & 0.93 & 0.49 & \\ & (0.90-0.96) & (0.47-0.51) & \\ \text { 4 A-1 C } & 0.73 & 0.38 & 0.28 \\ & (0.72-0.74) & (0.37-0.39) & (0.27-0.31) \\ \text { 10 A-1 LV } & 0.74 & 0.37 & \\ & (0.71-0.75) & (0.36-0.39) & \\ \text { 4 A-1 RV } & 0.71 & 0.36 & \\ & (0.70-0.74) & (0.35-0.37) & \\ \text { 10 A-2 } & 0.56 & 0.28 & \\ & (0.51-0.60) & (0.26-0.31) & \\ \text { 2 A-3 } & 0.43 & 0.22 & \\ \text { 1 A-4 } & 0.35 & 0.19 & \end{array}$

Remarks. The present species is most similar to Propontocypris sp. A of the present study, but the dorsal margin is lower posterodorsally and has a rounded posterior cardinal angle. These two species belong to the same morphological group as $P$. crocata and $P$. quasicrocata Maddocks, 1969 from the Recent of Madagascar and $P$. supertrigonella sp. nov. of the present study and Propontocypris sp. 1 of Jain (1978), from the Recent off Western India, but differ in being larger. The present species is also distinctive in that the juveniles possess a strong posteroventral spine on each valve. The present species is very similar to Propontocypris sp. A Whatley et al. from Port Darwin, N. Australia but the latter is $0.2 \mathrm{~mm}$ shorter and rather less acuminate in the LV.

Propontocypris supertrigonella sp. nov. (Fig. 4, no. 25; Pl. 2, figs 13-17)

Derivation of name. $\mathrm{L}$; with reference to the distinctly triangular shape of the species in lateral view.

Holotype. C, OS 16203.

Paratypes. C, OS 16202; LV, OS 16179; C, OS 16201.

Locality and horizon. Sample 20, 100 feet offshore, west of Point Cruz, Honiara Bay, Guadalcanal. 2 fathoms. Unconsolidated, medium-grained coral sand. Recent.

Material. 14 valves and carapaces, A-4 to adult. Sample 20 Guadalcanal.
Diagnosis. A species of Propontocypris triangular in lateral view, posterior acuminate with sub-ventral apex; ventral margin very gently biconvex. Over 60 anterior marginal pore canals opening in a double row of pores just proximal of outer margin.

Description. Medium to large, moderately thin shelled. Brown in colour. Triangular in lateral view: sub-lenticular in dorsal view. Anterior margin well rounded: extremity at mid-height. Posterior margin acuminate, extremity sub-ventral. Dorsal margin angularly convex, angle just anterior to mid-length. Ventral margin very gently biconvex. Maximum length sub-ventral; maximum height through dorsal angle; maximum width median. Valve surface smooth. Npcs very numerous, small, simple. Inner lamella wide, fused zone narrow. Large semi-circular vestibulae. Rpcs very numerous, all opening just proximal to the outer margin; over 60 canals anteriorly, opening in a double row and about 20 canals posteriorly. Hinge adont. Central muscle scars a rosette of five elongate scars, one dorsally and four ventrally in two horizontally aligned rows.

\section{Dimensions.}

$\begin{array}{llll} & \text { Length } & \text { Height } & \text { Width } \\ \text { Holotype C, OS 16203 } & 0.94 & 0.36 & \text { open } \\ \text { Paratype C, OS 16202 } & 0.93 & 0.35 & \text { open } \\ \text { Paratype C, OS 16201 } & 0.94 & 0.33 & \text { open } \\ \text { Paratype LV, OS 16179 } & 0.92 & 0.33 & \\ \text { Mean dimensions. } & & & \\ \text { 6 C } & 0.68 & 0.35 & \\ & (0.65-0.71) & (0.33-0.36) & \\ \text { 4 A-1 } & 0.55 & 0.27 & \\ & (0.52-0.57) & (0.26-0.28) & \\ \text { 2 A-2 } & 0.43 & 0.21,0.22 & \\ \text { 1 A-3 } & 0.34 & 0.17 & \\ \text { 1 A-4 } & 0.28 & 0.15 & \end{array}$

Remarks. The present species is conspicuously smaller than the other species of Propontocypris encountered in the present material. It is distinctly triangular in shape with a rounded posterior extremity. The present species is most similar in shape to $P$. quasicrocata Maddocks, 1969 from the Recent off Madagascar, but the anterodorsal margin is longer, the anterior margin narrower and it is slightly larger in size.

Propontocypris sp. A

(Fig. 4, nos 19, 22; Pl. 2, fig. 10)

Material. Four adult valves and 21 juvenile valves to A-4. Samples 2, 13, 14, 17, 29, 30, 41, 42, 53, 56, 57, 61 Guadalcanal.

\section{Dimensions.}

RV, OS 16176

LV, OS 16173

$\mathrm{LV}$,

A-1 LV

A-1 RV

A-2 LV

A-3 RV

A-4 RV

Length
0.93
0.92
0.89
0.73
0.73
0.59
0.47
0.40

Height

0.51

0.50

0.49 broken

0.43

0.41

0.32

0.25

0.22 
Remarks. The present species is distinctive in that both adult valves possess a strong posterior, terminal spine. Pontocypris herdmani (Scott, 1905) of Maddocks, 1969 from the Recent of the Bay of Bengal has such a spine on the RV only. The present species, like $P$. supertrigonella $\mathrm{sp}$. nov. and $\mathrm{P}$. paracrocata $\mathrm{sp}$. nov., belongs to the same morphological group as $P$. crocata Maddocks, 1969.

\section{Propontocypris sp. B}

(Fig. 4, nos 23, 26; Pl. 1, figs 8, 10-11)

Material. Three adult and seven juvenile valves to A-2 instar. Samples 13-15, 17, 57 Guadalcanal.

Dimensions.

$\begin{array}{llll} & \text { Length } & \text { Height } & \text { Width } \\ \text { LV, OS 16177 } & 0.62 & 0.32 & \\ \text { RV, OS 16180 } & \text { broken } & & \\ \text { LV, OS 16186 } & 0.64 & 0.33 & \\ \text { A-1 RV } & 0.51 & 0.24 & \\ \text { A-2 C } & 0.41 & 0.20 & 0.17\end{array}$

Remarks. The present species is very unusual in that the fused zone of the inner lamella is widened ventrally (similar to Argilloecia). This feature has not been described before in Propontocypris but in all other characters it is consistent with the genus. Its smaller size and character of the inner lamella distinguish it from the other species of Propontocypris encountered in the present study. Propontocypris sp. C is larger and more bluntly rounded posteriorly. The species described above is probably new but as it is only represented by two unbroken adult LV, it is left nomina aperta. This and the next species are more similar to the subgenus Ekpontocypris Maddocks, 1969 than are the preceding species. However, the authors are not confident that they can consistently recognize the two subgenera and, therefore, prefer not to use them.

\section{Propontocypris sp. C}

(Fig. 4, nos 17, 20; Pl. 2, figs 24, 29)

Material. Two adult valves and ten juveniles to A-2 instar. Samples 13, 17, 32, 40, 55, 57 Guadalcanal.

\section{Dimensions.}

$\begin{array}{llll} & \text { Length } & \text { Height } & \text { Width } \\ \text { LV, OS 16171 } & 0.74 & 0.40 & \\ \text { RV, OS 16174 } & 0.68 & 0.34 & \\ \text { A-1 C } & 0.57 & 0.29 & 0.24 \\ \text { A-2 C } & 0.45 & 0.22 & 0.20\end{array}$

Remarks. The present species is very similar in shape to several other species of the genus; however, it is difficult to compare this species accurately as only two adult valves were found and no soft parts preserved. Propontocypris litoricola Maddocks, 1969 from the Recent of the Indian Ocean, resembles the present species in size and shape but is slightly more extended posteriorly and differs in central muscle scar pattern. Propontocypris davisoni (Brady) 1868 from the Recent around Mauritius, is considerably larger than the present species and Propontocypris sp. A of the present study is smaller, more acuminate posteriorly and possessing a wide fused zone ventrally.

\author{
Suborder Platycopina Sars, 1866 \\ Family Cytherellidae Sars, 1866 \\ Genus Cytherella Jones, 1849 \\ Cytherella semitalis Brady, 1868 \\ (P1. 3, figs 1-8)
}

1868 Cytherella semitalis Brady: 72, pl. 18, figs 23, 24.

2001 Cytherella semitalis Brady; Titterton et al., 42, pl. 3, figs 10, 11 (q.v. for synonymy).

Type species. Cytherina ovata Roemer, 1840.

Diagnosis. Adults conspicuously dimorphic; female strongly inflated posteriorly and wider than male. Surface of valves with large, deep fossae around a smooth, elongate median and muscle scar area; not extending to margins except anteriorly and posteriorly where fossae are smaller, weaker and more dense. Size of fossae varies between individuals but there are essentially three rows both dorso- and ventro-medianly.

Material. 271 valves and carapaces, A-4 to adult. Honiara Bay samples 5, 13-17, 29, 30, 40-42, 52-58, 60, 61, and in sample OS6 from Shortland Island.

\section{Dimensions.}

Length

Height

Width

$\begin{array}{lll}0.61 & 0.33 & 0.27 \\ (0.59-0.63) & (0.33-0.35) & (0.26-0.28) \\ 0.56 & 0.29 & \\ (0.53-0.62) & (0.28-0.33) & \\ 0.58 & 0.32 & \\ (0.54-0.62) & (0.29-0.35) & \\ 0.52 & 0.26 & 0.18 \\ 0.55 & 0.27 & \\ (0.51-0.57) & (0.25-0.30) & \\ 0.55 & 0.29 & \\ (0.52-0.58) & (0.27-0.30) & \\ 0.50 & 0.26 & 0.22 \\ 0.50 & 0.26 & \\ (0.48-0.54) & (0.25-0.27) & \\ 0.51 & 0.28 & \\ (0.48-0.57) & (0.26-0.29) & \\ 0.44 & 0.24 & \\ (0.41-0.46) & (0.22-0.26) & \\ 0.38 & 0.22 & \\ (0.37-0.40) & (0.20-0.24) & \\ 0.33 & 0.19 & \\ (0.27-0.35) & (0.16-0.20) & \\ & & \end{array}$

Female C, OS 16214

Male C, RT/SIR/818

Male LV, OS 16213

Female LV, OS 16211

Female RV, OS 16212

Male RV, RT/SIR/822

Female RV, OS 16215

Male LV, OS 16216

Mean dimensions.

5 C Female

18 LV Female

0.62

0.55

0.56

0.32

0.27

0.26

$0.58 \quad 0.33$

$\begin{array}{ll}0.60 & 0.32\end{array}$

$\begin{array}{ll}0.66 & 0.28\end{array}$

$\begin{array}{ll}0.58 & 0.34\end{array}$

$\begin{array}{ll}0.58 & 0.30\end{array}$

17 RV Female

1C Male

17 LV Female

5 RV Male

0.26

0.20

1 A-1 C

17 A-1 LV

15 A-1 RV

23 A-2

14 A-3

$6 \mathrm{~A}-4$ 


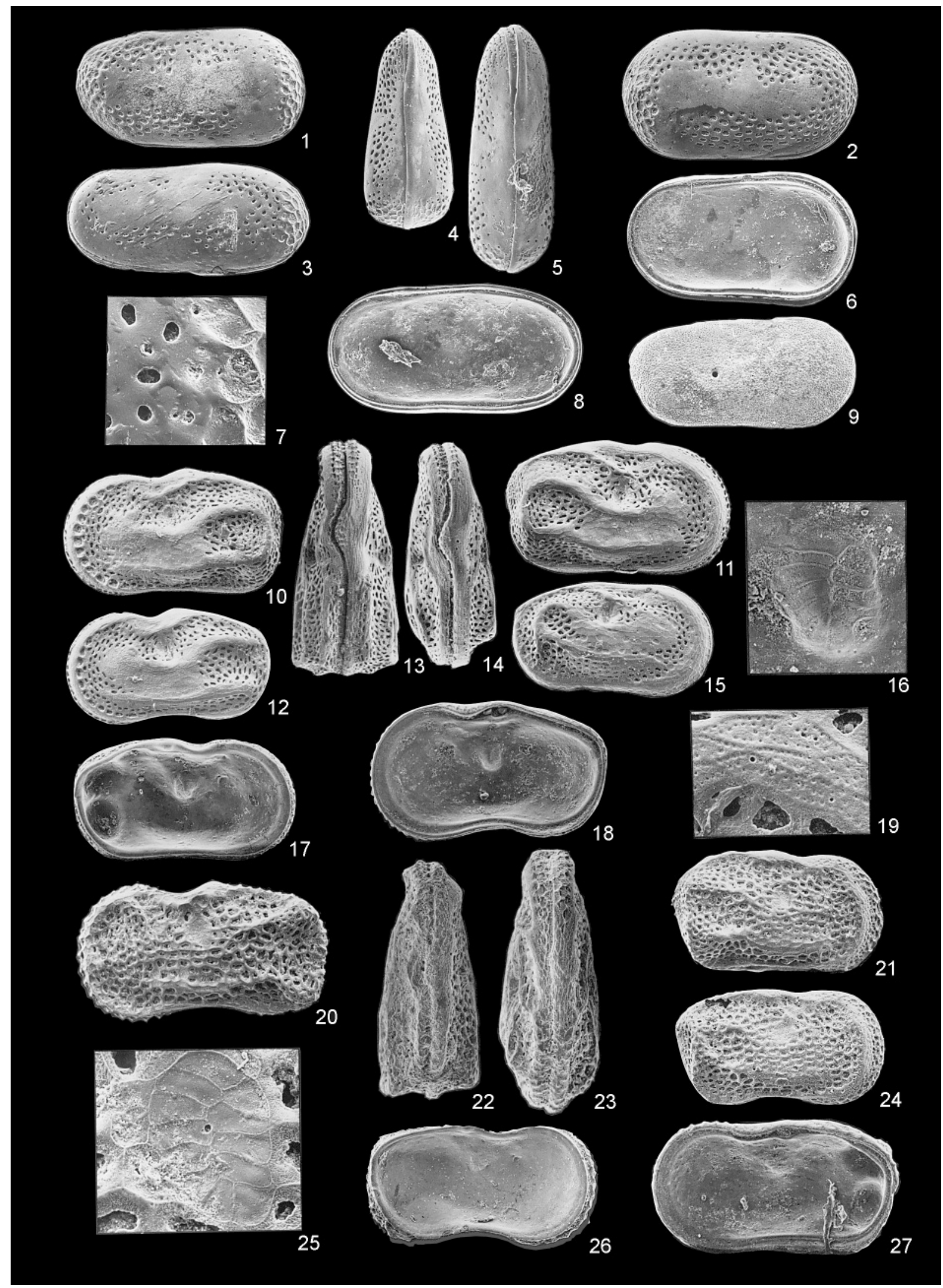


Occurrence. Cytherella semitalis was first described from soundings taken near North Watcher Island, off northern Java (Brady, 1868). In the Recent the species occurs as far west as the western coast of India, at Mandvi Beach (Jain, 1978). It was recorded by Brady (1880) from 37 fathoms in Humbolt Bay, Papua New Guinea, 16 fathoms off Booby Island and in muds dredged from 28 fathoms in the Torres Straits. It also occurs in the Eastern Java Sea (Kingma, 1948) and off Eastern Australia (Chapman, 1941). The furthest east it has been recorded is New Caledonia and Fiji (Brady, 1890). The earliest fossil record is from the Lower Miocene of New Zealand (Swanson, 1969), the Pliocene of the Solomon Islands (Hughes, 1977) and Sumatra (LeRoy, 1940). Kingma (1948) recorded it in Lower Pliocene sediments from Atjeh, Northern Sumatra and Upper PliocenePleistocene from Sangiran, Java, and Fyan (1916) from the Upper Pliocene? of Timor. Cytherella semitalis also occurs in offshore Quaternary marine sediments from Guadalcanal (Williams, 1980).

Remarks. Several somewhat similar species of Cytherella have been described from the Pacific region (e.g. Whatley et al., 1995); the major criterion for distinguishing them being ornament. The ornament in the present species is very variable but in all specimens the puncta did not extend to the dorsal and ventral margins.

\section{Cytherella sp. A}

(P1. 3, fig. 9)

Material. Two adult RV. Shortland Island, sample OS6.

\section{Dimensions.}

RV, OS 16217

Length

0.64

Height

0.33

Remarks. The present species is probably new but is represented by only two specimens. It is elongate, sub-rectangular in shape and ornamented by minute puncta that are concentric with the margins. Cytherella sp. 1 of Hartmann, 1979 (Recent eulittoral of Southern Australia) and Cytherella inchoata Zhao \& Whatley (1989) from Malaya are very similar in also possessing a punctate ornament, but are much less rectangular. They also differ from the present species in possessing a narrow arc of reticulae posteriorly.

Genus Cytherelloidea Alexander, 1929

1981 Keijcyoidea Malz: 16.
Type species. Cytherella williamsoniana Jones, 1849.

Remarks. Keijcyoidea was erected to accommodate species with a hinge tooth dorsally in either valve. In five of the seven species encountered in the present study, the selvage is modified middorsally to form a strong tooth in the left valve and a complementary socket in the right valve. In Cytherella keiji McKenzie, 1967 and C. reticulata sp. nov. the tooth is situated just posterior to the concavity of the dorsal margin, whereas in the present material in C. asymmetrica sp. nov., Cytherelloidea sp. A and Cytherelloidea sp. B., it occurs at the dorsal concavity. This single feature is considered to be a specific character of Cytherelloidea, rather than of generic significance. It occurs as early as the Upper Cretaceous, with the anterodorsal projection of the RV being accommodated in a socket-like depression in the LV, as described for $C$. directangula Holden, 1964 (Upper Cretaceous, California) and C. biloculata Veen, 1932 (Upper Cretaceous, Netherlands). During the Tertiary in North America, several species of Cytherelloidea evolved with a toothed hinge structure. They are probably a separate lineage from the above two Cretaceous species, as the tooth is not developed in the RV, but in the LV. These include $C$. montgomereyensis Howe, 1934 (Eocene), C. cocoaensis Krutak, 1961 (Eocene) and C. umbonata Edwards, 1944 (Miocene). In these three species, the tooth is less well developed than in the Pacific lineage which appears to have evolved from $C$. semipunctata Holden, 1976 (Lower Miocene, Hawaii) giving rise to $C$. monodenticulata Holden, 1967 (Neogene, Hawaii) and C. keiji McKenzie, 1967 (Miocene-Recent, Southwestern Pacific and Australia). In the authors' opinion, Keijcyoidea is a junior synonym of Cytherelloidea.

\section{Cytherelloidea keiji McKenzie, 1967}

(Pl. 3, figs 10-19)

1963 ?Cytherelloidea sp Bold: 76, pl. 1, fig. 8

1967 Cytherelloidea keiji McKenzie: 63, pl. 11, figs 1, 3p.

1978 Cytherelloidea keiji McKenzie; Hartmann: 67, figs 1-6, pl. 1, figs 1-3.

1978 Cytherelloidea keiji McKenzie; Hartmann \& Kühl: 221, pl. 26, figs 13-24; pl. 28, figs 25-32.

1979 Cytherelloidea keiji McKenzie; Hartmann: 220.

1980 Cytherelloidea keiji McKenzie; Hartmann: 107.

1983 Cytherelloidea keiji McKenzie; Whatley \& Downing: 386, pl. 8, fig. 16 .

1989 Keijcyoidea keiji (McKenzie); Howe \& McKenzie: 4.

\section{Explanation of Plate 3}

figs 1-8. Cytherella semitalis Brady, 1868: 1, LVF, OS 16211 external lateral view $\times 81.0 ; 2$, RVF, OS 16212 external lateral view $\times 81.0 ; 3,7, \mathrm{LVM}$, OS 16213 - (3) external lateral view $\times 88.9$, (7) detail of lateral ornament $\times 434.8 ; 4, \mathrm{CF}$, OS 16214 dorsal view $\times 67.2 ; \mathbf{5}, \mathrm{CM}, \mathrm{RT} / \mathrm{SIR} / 818$ dorsal view $\times 98.9 ; 6$, RVF, OS 16215 internal view $\times 83.1 ; 8$, LVM, OS 16216 internal view $\times 88.9$. fig. 9. Cytherella sp. A, RV, OS 16217 external lateral view $\times$ 71.1. figs 10-19. Cytherelloidea keiji McKenzie, 1967: 10, LVF, RT/SIR/830 external lateral view $\times 66.3 ; 11,19 . \mathrm{RVF}$, OS 16218 - (11) external lateral view $\times 66.3$, (19) detail of lateral ornament $\times 592.9 ; \mathbf{1 2}, \mathrm{LVM}, \mathrm{RT} / \mathrm{SIR} / 828$ external lateral view $\times 67.4 ; 13, \mathrm{CF}, \mathrm{RT} / \mathrm{SIR} / 827 \mathrm{dorsal}$ view $\times 72.1 ; \mathbf{1 4}, \mathrm{CM}$, OS 16219 dorsal view $\times 74.4 ; \mathbf{1 5}$, RVM, OS 16220 external lateral view $\times 70.9 ; \mathbf{1 6}, \mathbf{1 8}, \mathrm{RVM}, \mathrm{RT} / \mathrm{SIR} / 832-(\mathbf{1 6})$ detail of central muscle scar $\times 395.3$, (18) internal view $\times 79.1$; 17. LVF, OS 16221 internal view $\times 65.2$. figs 20-27. Cytherelloidea dictyotos sp. nov.: 20, 25, Paratype LVM, OS $16222-(\mathbf{2 0})$ external lateral view $\times 83.0$, (25) detail of lateral ornament over central muscle scar area $\times 276.7 ; \mathbf{2 1}$, Holotype, RVF, OS 16223 external lateral view $\times 74.4$; 22, Paratype CF, OS 16224 dorsal view $\times 79.6$; 23, Paratype, CM, OS 16225 dorsal view $\times 87.8$; 24, Paratype RVM, OS 16226 external lateral view $\times 83.0 ;$ 26, Paratype LVM, OS 16227 internal view $\times 83.0 ; 27$, Paratype RVF, RT/SIR/842 internal view $\times 80.2$. 
1995 Keijcyoidea keiji (McKenzie); Yassini \& Jones: 302, figs 28, 29.

Material. 573 valves and carapaces, A-6 to adult. Shortland Island, samples OS5, OS6.

Dimensions.

\begin{tabular}{|c|c|c|c|}
\hline & Length & Height & Width \\
\hline Male C, OS 16219 & 0.61 & 0.36 & 0.24 \\
\hline Female C, RT/SIR/827 & 0.67 & 0.38 & 0.30 \\
\hline Male LV, RT/SIR/828 & 0.62 & 0.34 & \\
\hline Male RV, OS 16220 & 0.60 & 0.36 & \\
\hline Female LV, RT/SIR/830 & 0.65 & 0.36 & \\
\hline Female RV, OS 16218 & 0.68 & 0.39 & \\
\hline Male RV, RT/SIR/832 & 0.61 & 0.37 & \\
\hline Female LV, OS 16221 & 0.68 & 0.38 & \\
\hline Female RV, RT/SIR/834 & 0.70 & 0.40 & \\
\hline Male LV, RT/SIR/835 & 0.62 & 0.33 & \\
\hline \multicolumn{4}{|l|}{ Mean dimensions. } \\
\hline \multirow[t]{2}{*}{7 C Female } & 0.70 & 0.40 & 0.32 \\
\hline & $(0.67-0.72)$ & $(0.38-0.41)$ & \\
\hline \multirow[t]{2}{*}{13 LV Female } & 0.67 & 0.37 & \\
\hline & $(0.65-0.68)$ & $(0.36-0.38)$ & \\
\hline \multirow[t]{2}{*}{12 RV Female } & 0.68 & 0.40 & \\
\hline & $(0.66-0.74)$ & $(0.38-0.38)$ & \\
\hline \multirow[t]{2}{*}{5 C Male } & 0.63 & 0.35 & 0.25 \\
\hline & $(0.61-0.66)$ & $(0.34-0.36)$ & $(0.24-0.26$ \\
\hline \multirow[t]{2}{*}{11 LV Male } & 0.60 & 0.33 & \\
\hline & $(0.59-0.61)$ & $(0.32-0.34)$ & \\
\hline \multirow[t]{2}{*}{9 RV Male } & 0.61 & 0.35 & \\
\hline & $(0.60-0.62)$ & $(0.34-0.36)$ & \\
\hline \multirow[t]{2}{*}{14 A-1 LV } & 0.59 & 0.33 & \\
\hline & $(0.56-0.60)$ & $(0.31-0.34)$ & \\
\hline \multirow[t]{2}{*}{13 A-1 RV } & 0.61 & 0.36 & \\
\hline & $(0.57-0.63)$ & $(0.35-0.37)$ & \\
\hline \multirow[t]{2}{*}{$18 \mathrm{~A}-2$} & 0.51 & 0.30 & \\
\hline & $(0.49-0.54)$ & $(0.28-0.30)$ & \\
\hline \multirow[t]{2}{*}{14 A-3 } & 0.45 & 0.27 & \\
\hline & $(0.44-0.47)$ & $(0.25-0.29)$ & \\
\hline \multirow[t]{2}{*}{$10 \mathrm{~A}-4$} & 0.40 & 0.24 & \\
\hline & $(0.38-0.43)$ & $(0.22-0.27)$ & \\
\hline \multirow[t]{2}{*}{$6 \mathrm{~A}-5$} & 0.35 & 0.22 & \\
\hline & $(0.33-0.36)$ & $(0.21-0.23)$ & \\
\hline \multirow[t]{2}{*}{3 A-6 } & 0.31 & 0.21 & \\
\hline & $(0.30-0.31)$ & $(0.20-0.21)$ & \\
\hline
\end{tabular}

Occurrence. McKenzie (1967) recorded C. keiji in Recent sediments from Port Phillip Bay, Victoria, Australia. The species had been recorded previously but unnamed from the Recent of Auckland, New Zealand (Bold, 1963). Hartmann has recorded it from several shallow-water localities along the western (1978), southern (1979) and southeastern (1980) coasts of Australia. McKenzie \& Howe (1989) and Yassini \& Jones (1995) record it in northern and northeastern Australia. Whatley \& Downing (1983) found C. keiji in Middle Miocene sediments from Port Phillip Bay. Hughes (1977) also recorded C. keiji in Miocene sediments from Guadalcanal. It was also found in offshore marine Quaternary sediments from Guadalcanal (Williams 1980).
Remarks. Hartmann \& Kühl (1978) illustrated the ornamental variation of $C$. keiji. This is essentially in the area of the valve covered by the strong reticulate ornament, varying from being completely absent to covering the entire surface apart from on the lateral and marginal ribs. The only apparent difference between C. semipunctata, Cytherelloidea sp. 2 of Holden, 1976 both from the Pliocene of Midway Island, and $C$. keiji is the degree to which the reticulate ornament is developed. Holden also described a species comparable to C. umbonata Edwards, 1944 from the Miocene of Midway Island which differs in that the dorsal rib is less well developed and is absent anterior of the sulcus. Cytherelloidea praecipua Bold, 1963 (Recent, Tobago) is also very similar to $C$. keiji. Cytherelloidea reticulata $\mathrm{sp}$. nov. differs from all these species in that the reticulate ornament extends over the lateral ribs. Whatley et al. (2000) erected the subspecies $C$. keiji pasquaensis for cribrose reticulate specimens apparently confined to Easter Island.

\section{Cytherelloidea asymmetrica sp. nov. (Pl. 4, figs 10, 13-18, 20)}

Derivation of name. $L$; from the asymmetrical arrangement of the central muscle scars of this species.

Holotype. LVF OS 16235.

Paratypes. Female C, OS 16239; Male LV, OS 16238; Male RV, OS 16236; Female C, OS 16224; Male C, OS 16225; Female RV, OS 16223; Male LV, OS 16222; Male RV, OS 16226; Female RV, RT/SIR/842; Male LV, OS 16227.

Material. 26 valves and carapaces, A-1 to adult. Shortland Island, sample OS6.

Locality and horizon. Sample OS6. Exact location unknown, but thought to be from the intertidal zone near a coral reef, off the northeast coast of Shortland Island, in the vicinity of Rokuai Island. Coarse-grained coral sand. Recent.

Diagnosis. A species of Cytherelloidea possessing a strong reticulate ornament over most of the valve surface, in which the fossae are cribrose and irregular, becoming enclosed, particularly centrally. Central muscle scars a platycopine heartshaped cluster of 12 scars asymmetrically arranged with seven scars anteriorly and posteriorly. Selvage of LV modified to form a hinge tooth within concavity of dorsal margin with complementary socket in RV.

Description. Small to medium. Thick shelled, opaque. Sexually dimorphic; female subquadrate in lateral view and subtriangular in dorsal view; male kidney-shaped in lateral view and sub-elliptical in dorsal view. Anterior broadly rounded, posterior slightly narrower. Dorsal margin gently convex in RV, with slight concavity towards anterior in LV. Ventral margin biconvex. Maximum length at mid-height in LV, well above mid-height in RV; maximum height through anterior quarter; maximum width posteriorly in female, at posterior third in male. Male RV and both female valves similarly ornamented, male LV 
slightly different posteriorly. All valves with shallow median sulcus, an anterior sub-marginal rib from mid-dorsum to posteroventral angle, more peripheral ventrally; a short rib from mid-dorsum to anterior region and a rib from the anterior arch of the dorsal lateral rib curves posteriorly to merge with the dorsal margin. Two lateral ribs, the dorsal rib arches over sulcus, curving down then up again to the posterior where it continues parallel to posterior margin to join the ventral rib which is straight anteriorly and arched posteriorly. The male LV differs in that the dorsal rib does not curve down parallel to posterior but meets a posterior marginal rib at the posterior cardinal angle; this posterior rib joins the central lateral rib. Valve surface deeply reticulate; fossae cribrose and irregular becoming enclosed, particularly centrally. Hinge and ribs with faint secondary ribbing which forms a reticulate pattern with secondary pitting within fossae. Selvage modified mid-dorsally within dorsal concavity to form a strong, ovate tooth in LV and complementary socket in right. Central muscle scars on small elevation, which is the internal reflection of the median sulcus. Scar pattern platycopine, heart-shaped with 12 scars asymmetrically arranged, seven anterior and five posterior scars.

Dimensions.

$\begin{array}{llll} & \text { Length } & \text { Height } & \text { Widt } \\ \text { Paratype Female C, OS 16239 } & 0.52 & 0.30 & 0.22 \\ \text { Holotype Female LV, OS 16235 } & 0.52 & 0.29 & \\ \text { Female RV, OS 16240 } & 0.54 & 0.29 & \\ \text { Paratype Male LV, OS 16238 } & 0.50 & 0.30 & \\ \text { Male LV, OS 16237 } & 0.46 & 0.28 & \\ \text { Paratype Male RV, OS 16236 } & 0.57 & 0.31 & \\ \text { Female LV, RT/SIR/849 } & 0.54 & 0.30 & \end{array}$

Remarks. The present species differs from Cytherelloidea reticulata and related species in that the hinge tooth is not posterior to, but is within the concavity of the dorsal margin. It also differs in ornament in that the dorsal rib extends over, and not below, the median sulcus. Cytherelloidea sp. A of the present study is less strongly reticulate and the fossae are more rounded in shape.

\section{Cytherelloidea dictyotos sp. nov. (P1. 3, figs 20-27)}

Derivation of name. $G r$; from $\delta 1 \kappa \tau v v$ a net, thus $\delta 1 \kappa \tau \nu \omega \tau o \varsigma$ (dictyotos), reticulate. With reference to the reticulate ornament covering the entire surface of the valves.

Holotype. RVF OS 16223.

Paratypes. Female C, OS 16224, Male C, OS 16225, Male LV, OS 16222, Male RV, OS 16226, Male LV, OS 16227, Female RV, RT/SIR/842.

Locality and horizon. Sample OS6, exact location, unknown but thought to be from the intertidal zone near a coral reef off the northeast coast of Shortland Island, in the vicinity of Rokuai Island. Coarse-grained coral sand. Recent.
Material. 14 valves and carapaces, A-1 to adult. Shortland Island, samples OS5, OS6.

Diagnosis. A species of Cytherelloidea sub-rectangular in lateral view, female sub-triangular in dorsal view, male sub-elliptical. Entire surface of valves apart from the anterior sub-marginal rib is strongly reticulate, fossae deep and irregular, muri broad with faint secondary reticulation along crests. Muscle scar conspicuous in external view. Selvage of left valve modified to form a hinge tooth just posterior to the dorsal concavity with complementary socket in right valve.

Description. Medium. Thick shelled. Opaque. Sexual dimorphism conspicuous; female strongly inflated posteriorly, subtriangular in shape in dorsal view, male sub-elliptical, both sexes sub-rectangular in lateral view. Anterior broadly rounded, posterior slightly narrower, rounded in LV, almost straight in RV. Dorsal biconvex, more strongly so in LV, concavity just anterior to mid-length. Ventral biconcave, more strongly so in male. Maximum length a mid-height in LV, well above mid-height in $\mathrm{RV}$; maximum height through anterior quarter; maximum width at posterior third in male, posteriorly in female. Shallow median sulcus, just dorsal of centre within which external view of central muscle scars conspicuous. Male RV and both female valves most similarly ornamented with two strong, lateral ribs below the sulcus, extending from anterior region almost to posterior margin where they meet a third, vertical rib which extends from the dorsal lateral rib to the posteroventral angle. In male LV the dorsal rib curves to the posterior cardinal angle and the ventral rib to the posteroventral angle where they are more strongly inflated. RV of both sexes with sub-peripheral anterior rib from mid-dorsum to oral concavity, bearing a faint, diamond-shaped secondary reticulate ornament. LV of both sexes with anterior rib more peripheral and stronger. Valve surface reticulate, fossae deep, irregular; muri broad with faint reticulation, like anterior rib, along crests. Selvage modified mid-dorsally just posterior of concavity into strong, ovate tooth in LV with complementary socket in RV. Central muscle scars on elevated area, which is an internal reflection of median sulcus; pattern typically Platycopine comprising 12 scars. Female with two shallow posterior concavities.

\section{Dimensions.}

Paratype Female C, OS 16224

Paratype Male C, OS 16225

Holotype Female RV, OS 16223

Paratype Male LV, OS 16222

Paratype Male RV, OS 16226

Paratype Male LV, OS 16227

Paratype Female RV, RT/SIR/842

$\begin{array}{lll}\text { Length } & \text { Height } & \text { Width } \\ 0.58 & 0.32 & 0.25 \\ 0.52 & 0.28 & 0.19 \\ 0.58 & 0.33 & \\ 0.54 & 0.29 & \\ 0.53 & 0.29 & \\ 0.54 & 0.28 & \\ 0.57 & 0.34 & \end{array}$

Remarks. The present species is rather similar to $C$. keiji in shape, internal characters, position of hinge tooth and distribution of lateral ribs. The ornament differs, however, in that the entire surface of the valves, apart from the anterior rib, is strongly reticulate. This is well beyond the morphological variation observed in C. keiji illustrated by Hartmann \& Kühl (1978). 


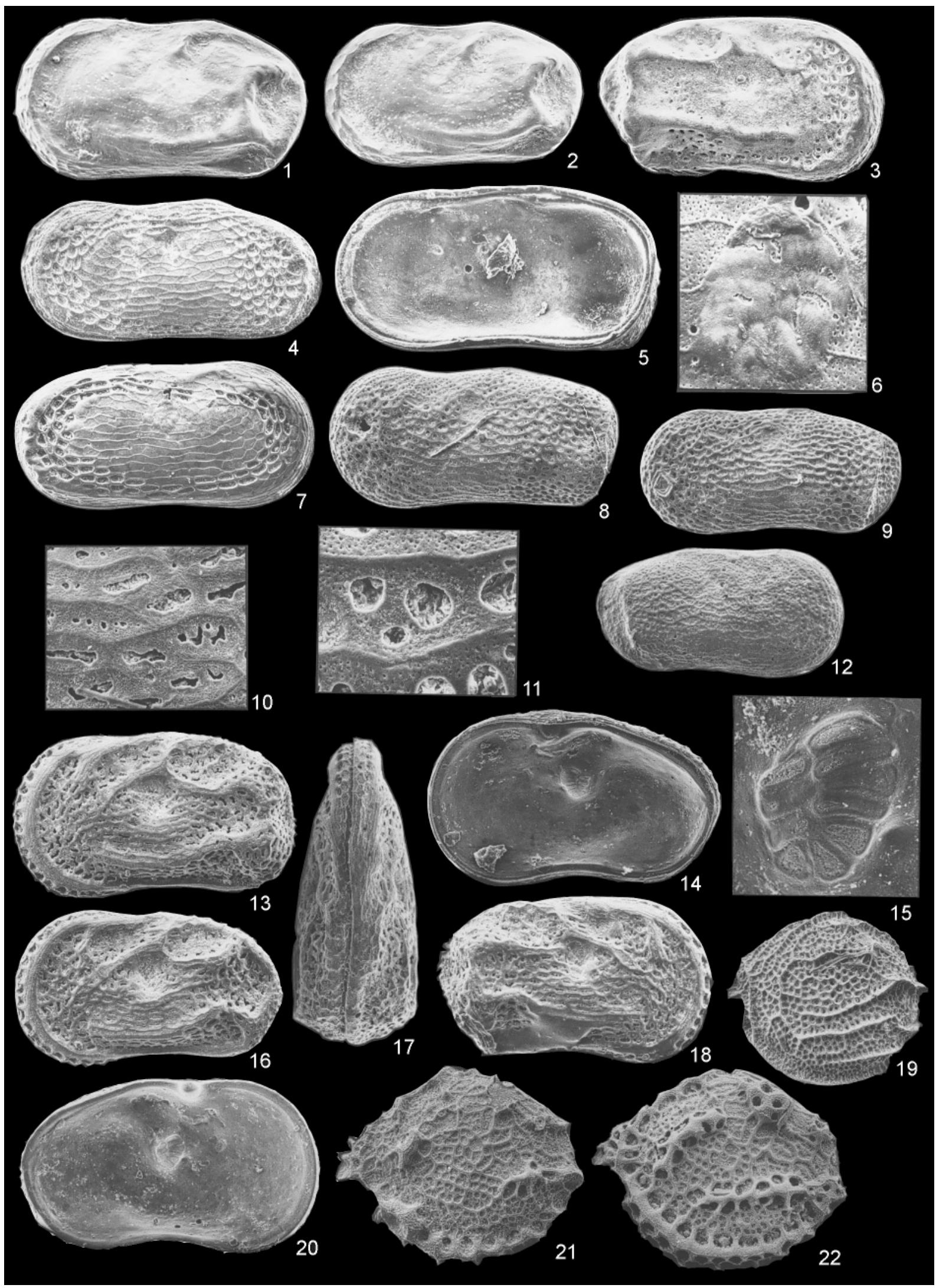


Cypridoidea, Platycopina \& Cladocopina, Solomon Islands

Cytherelloidea sp. cf. Cytherelloidea sp. 1 Holden, 1976 (P1. 4, figs 8-9, 11-12)

1976 Cytherelloidea sp 1 Holden: 39; pl. 16, fig. 2.

Material. Two adult left valves and one A-1 instar right valve. Shortland Island, sample OS6.

Dimensions.

Female LV, OS 16232

Male LV, OS 16233

A-1 RV, OS 16234

Length
0.70
0.64
0.58

Height

0.33

0.30

0.29

Remarks. The present species has been assigned to Cytherelloidea as the female possesses two internal posterior concavities. The surface of the valves, although lacking longitudinal ribs, is strongly reticulate with a vertical posterior rib. The present species is most similar to Cytherelloidea sp. 1 of Holden, 1976 from the Pleistocene of Hawaii and may even be conspecific. It is also similar to Cytherelloidea sp. C of the present study, but differs in that the latter possesses anterior and posterior submarginal ribs. The reticulate ornament also differs as Cytherelloidea sp. C possesses a marginal arc of large, open reticulae anteriorly and posteriorly with a delicately reticulate central area. The present species lacks these large, open reticulae.

\section{Cytherelloidea sp. A \\ (P1. 4, fig. 3)}

Material. One adult and five juvenile valves to A-2 instar. Honiara Bay, samples: 32, 53, 55.

Dimensions.

RV, OS 16230
Height

Remarks. This species is closely related to C. asymmetrica $\mathrm{sp}$. nov. and Cytherelloidea sp. B of the present study, as the tooth structure occurs at the dorsal concavity. It is somewhat similar in primary ornament to $C$. asymmetrica but differs in that its reticulae are less ubiquitous and are oval or rounded in shape. It differs in ornament to $C$. keiji in that the two lateral ribs in $C$. keiji pass below the sulcus, whereas in the present species, the dorsal lateral rib passes above the sulcus.

\section{Cytherelloidea sp. B}

(P1. 4, figs 1-2)
Material. Two adult left valves. Shortland Island, sample OS6.

\section{Dimensions.}

Female LV, OS 16228

Male LV, OS 16229

Length

Height

0.51

0.29

0.48

0.27

Remarks. The present species differs from C. keiji and related species in the position of the dorsal hinge tooth and in its ornament as the dorsolateral rib is not present and the ventrolateral rib extends to the posteroventral angle. A second posterior rib extends from the posterior cardinal angle and arches towards the anterior, meeting the ventrolateral rib posteriorly. A strong, anterior sub-marginal rib is present, anterior to which is a narrow reticulate area. The surface of the valve is very delicately reticulate with a single line of punctae along the muri of the reticulae. Some puncta are sieve-type normal pore canals.

\section{Cytherelloidea sp. C}

(P1. 4, figs 4-7)

Material. Five adult valves. Honiara Bay, samples 2, 15, 29; Shortland Island, sample OS6.

\section{Dimensions.}

Male LVM, OS 16231

Length Height

Female RV, RT/SIR/857

0.64

0.29

Male RV, RT/SIR/858

0.68

0.33

0.60

0.29

Remarks. The surface of the valves of the present species are reticulate. Marginally the ornament is strongly developed with deep, ovate fossae. The reticulate ornament changes centrally, becoming delicate with diamond shaped fossae within which is a dense, secondary punctate ornament. Cytherelloidea venusta (Brady) 1880 from Honolulu also possesses this diamondshaped, delicate reticulation but not the more deeply etched reticulum marginally. Cytherelloidea sp. B Whatley \& Keeler (1989) from the Recent of St. Pierre Harbour, Reunion Island, South Western Indian Ocean, is probably identical to the present species, which, although new, is left in open nomenclature due to its rarity.

Order Myodocopida Sars, 1866

Suborder Cladocopina Sars, 1866

Family Polycopidae Sars, 1866

Genus Polycope Sars, 1866

Polycope sp. A

(Pl. 4, figs 21-22)

Explanation of Plate $4 .$.

figs 1-2. Cytherelloidea sp. B: 1, LVF, OS 16228 external lateral view $\times 85.8$; 2, LVM, OS 16229 external lateral view $\times 85.8$. fig. 3. Cytherelloidea sp. A, RV, OS 16230 external lateral view $\times 88.7$. figs 4-7. Cytherelloidea sp. C: 4, LVM, OS 16231 external lateral view $\times 73.3 ; 5, \mathrm{RVF}, \mathrm{RT} / \mathrm{SIR} / 857$ internal view $\times 77.0 ; \mathbf{6}, 7, \mathrm{RVM}, \mathrm{RT} / \mathrm{SIR} / 858-(\mathbf{6})$ detail of lateral ornament over central muscle scar area $\times 534.8,(7)$ external lateral view $\times 85.8$. figs 8-9, 11-12. Cytherelloidea sp. cf. Cytherelloidea sp. 1 Holden, 1976: 8, 11, LVF, OS $16232-(\mathbf{8})$ external lateral view $\times 67.0,(11)$ detail of lateral ornament $\times 670.0 ; 9$, LVM, OS 16233 external lateral view $\times 69.0 ; \mathbf{1 2}$, A-1 RV, OS 16234 external lateral view $\times 69.0$. figs $\mathbf{1 0}, \mathbf{1 3}-\mathbf{1 8}$, 20. Cytherelloidea asymmetrica sp. nov.: 10, 13, Holotype LVF, OS $16235-(\mathbf{1 0})$ detail of lateral ornament $\times 439.5$, (13) external lateral view $\times 87.9$; 14, Paratype RVM, OS 16236 internal view $\times 108.2 ; \mathbf{1 5}$, 20, LVM, OS 16237 - (15) detail of central muscle scars $\times 502.2,(\mathbf{2 0})$ internal view $\times 104.9$; 16, Paratype LVM, OS 16238 external lateral view $\times 83.7$; 17, Paratype CF, OS 16239 dorsal view $\times 94.1$; 18, RVF, OS 16240 external lateral view $\times$ 73.3. fig. 19. Polycope sp. B, JLV, OS 16241 external lateral view $\times 140.2$. figs 21-22. Polycope sp. A: 21, JLV, OS 16242 external lateral view $\times 140.2 ; 22, \mathrm{LV}$, OS 16243 external lateral view $\times 106.4$. 
Type species. Polycope orbicularis Sars 1866.

Material. Two left valves. Honiara Bay, samples 14, 17.

Dimensions.

$\begin{array}{lll}\text { Juvenile LV, OS } 16242 & 0.29 & 0.23 \\ \text { LV, OS } 16243 & 0.38 & 0.29\end{array}$

Remarks. The two specimens of this species are not identical in ornament, although the basic pattern is similar. The smaller specimen is believed to be a juvenile and the ornament not fully developed. The elaborate ornament and distinct anterior rostrum distinguishes the present species from any other Polycope known to the authors, which because of the paucity of material is retained under nomina aperata.

Polycope sp. B
(Pl. 4, fig. 19)

Material. One left valve, probably juvenile. Honiara Bay, sample 17.

Dimensions.

Juvenile LV, OS 16241

Length

Height

Remarks. This specimen is believed to be a juvenile. It differs from Polycope sp. A of the present study in that the ornament is more densely and deeply reticulate and the secondary papillate ornament absent. Some of the muri of the reticulae are developed into a series of ribs that extend sub-parallel to the margins, except centrally where the ribs form an 'L'-shape. The two ventro-lateral ribs extend to the posterior margin where they form two short spines. The present species is similar to the juveniles of Polycope sanctacatherinae Whatley \& Downing, 1983, from the Miocene of Victoria, Southeastern Australia, but it is less strongly ornamented.

\section{CONCLUSIONS}

Sampling of the Solomon Island fauna was confined to the two sampling localities, Guadalcanal and Shortland islands. It is, therefore, impossible to estimate what proportion of the total fauna the 160 species actually represents. From the authors' knowledge of the total diversity of faunas from adjacent areas within similar latitudinal confines, and from similar shallowwater environments (for example, the eastern and western tropical/subtropical coasts of Australia and the Southern Pacific islands of Samoa, Fiji and New Caledonia), it would seem on the basis of simple diversity comparisons, that the fauna is probably representative. A greater number of species and genera were encountered in the present fauna (160 species, 56 genera) than those from Eastern Australia ( 75 species, 38 genera) (Hartmann, 1981), Western Australia (91 species, 35 genera) (Hartmann, 1978) and New Caledonia, Fiji and Samoa (68 species, 14 genera) (Brady, 1890).

Aspects of the Solomon Island fauna from both islands which were also observed in the faunas from comparable environments are the conspicuous diversity of the marine Cypridoidea,
Bairdiidae, Loxoconchidae, Paradoxostomatidae and the Xestoleberidae and of the Cytherellidae in Honiara Bay. This paper illustrates the diversity of the marine Cypridoidea and of the Cytherellidae.

\section{ACKNOWLEDGEMENTS}

The authors thank Eden Fundingsland for creating the plates and figure and her assistance in their design and layout. The support provided by Statoil ASA, Stavanger is also acknowledged. The samples were kindly made available by Wynn Hughes and Colin Turner. Thanks must also go to the reviewers, in particular to John Whittaker for critically evaluating the original submission and his suggested improvements in content and scope. Giles Miller at the NHM, London is thanked for assistance in numbering the specimens.

\section{Manuscript received 25 July 2005 Manuscript accepted 7 December 2005}

\section{REFERENCES}

Alexander, C.I. 1934. Ostracoda of the Midway (Eocene) of Texas. Journal of Paleontology, 8 (2): 206-237.

Behrens, P. 1991a. Ostracoda (Crustacea) from Lizard Island, northern Great Barrier Reef, Australia I. Families: Cytherellidae, Loxoconchidae, Cythereideidae, Cytheruridae, Paracytherideidae, Pectocytheridae, Krithidae, Cytheromatidae, Bythocytheridae, Cytheridae. Helgoländer Meeresuntersuch, 45: 107-142.

Behrens, P. 1991b. Ostracoda (Crustacea) from Lizard Island, northern Great Barrier Reef, Australia II. The family Paradoxostomatidae Brady \& Norman, 1889. Helgoländer Meeresuntersuch, 45: 143-163.

Bold, W.A. van den 1963. Anomalous hinge structure in a new species of Cytherelloidea. Micropaleontology, 9 (1): 75-78.

Brady, G.S. 1866. On new or imperfectly known species of marina Ostracoda. Transactions of the Zoological Society of London, 5 (5): 359-393.

Brady, G.S. 1868. Ostracoda. In: De Folin, L. \& Perier, L. (Eds), Les Fonds de la Mer, 1. Savy, Paris, 316pp.

Brady, G.S. 1880. Report on the Ostracoda. Report of the Scientific Results of the Voyage of H.M.S. Challenger, 1873-1886; Zoology, 1(3): $184 \mathrm{pp}$

Brady, G.S. 1890. On Ostracoda collected by Mr. H. B. Brady, Esq, L.L.D, F.R.S., in the South Sea Islands. Transactions of the Royal Society of Edinburgh, 35: 489-525.

Brady, G.S. 1911. Notes on marine Ostracoda from Madeira. Proceedings of the Zoological Society of London, 1911 (2): 595-601.

Cabioch, G., Anglada, R. \& Babinot, J.F. 1986. Microfaunas et paléoenvironments des récifs frangeants quatenaires de Mamie et Ricaudy (Nouvelle-Calédonie). Cahiers de Micropaléontologie, n.s., 1 (1/2): 5-36.

Chapman, F. 1910. On the Foraminifera and Ostracoda from soundings (chiefly deep-water) collected from around Funafuti by H.M.S. 'Penguin'. Journal of the Linnean Society of London, Zoology, 30 (202): 388-444

Chapman, F. 1941. Report on foraminiferal soundings and dredgings of the F. I. S. Endeavour along the continental shelf of the south east coast of Australia. Transactions of the Royal Society of South Australia, 65: 145-211.

Chapman, F. \& Crespin, I. 1928. Super-Order Ostracoda. In: Chapman, F., Crespin, I. \& Keble, R. A. (Eds). The Sorrento Bore, Mornington Peninsula, with a description of new or little-known fossils. Records of the Geological Survey of Victoria, 5 (1): 1-195.

Dewi, K.T. 1997. Ostracoda from the Java Sea, west of Bawean Island, Indonesia. Marine Geological Institute, Special Publication, 4: 1-86.

Edwards, R.A. 1944. Ostracoda from the Duplin Marl (Upper Miocene) of North Carolina. Journal of Paleontology, 18: 505-528. 
Fyan, E.C. 1916. Eenige-jong Pliocene Ostracoden van Timor. Proceedings of the Section of Sciences, Koninklijke Nederlandse Akademie van Wetenschappen te Amsterdam, 24: 1175-1186.

Harding, J.P. 1962. Mungava munda and four other new species of ostracod crustaceans from fish stomachs. Natural History of Rennel Island, British Solomon Islands, 4: 51-62.

Hartmann, G. 1978. Die Ostracoden der Ordnung Podocopida G. W. Müller, 1894 der tropisch-subtropischen Westküste Australiens (zwischen Derby im Norden und Perth im Süden). In: HartmannSchroder, G. \& Hartmann, G. (Eds). Zur Kenntnis des Eulittorals der australischen Küsten unter besonderer Berücksichitung der Polychaeten und Ostracoden. Teil 1. Mitteilungen aus den Hamburgischen Zoologischen Museum und Institut, 75: 63-219.

Hartmann, G. 1979. Die Ostracoden der Ordnung Podocopida G. W. Müller, 1894 der warmtempereritein und subtropisch-tropischen Kustenabschnitte der Süd- und Südwestküste Australiens (zwischen Perth im Norden und Eucla im Süden). In: Hartmann-Schroder, G. \& Hartmann, G. (Eds). Zur Kenntnis des Eulittorals der australischen Küsten unter besonderer Berücksichitung der Polychaeten und Ostracoden. Teil 3. Mitteilungen aus den Hamburgischen Zoologischen Museum und Institut, 76: 219-301.

Hartmann, G. 1980. Die Ostracoden der Ordnung Podocopida G. W. Müller, 1894 der warmtempereritein und subtropisch-tropischen Kustenabschnitte der Süd- und Südosttküste Australiens (zwischen Ceduna im Western und Lakes Entrance in Osten). In: HartmannSchroder, G. \& Hartmann, G. (Eds). Zur Kenntnis des Eulittorals der australischen Küsten unter besonderer Berücksichitung der Polychaeten und Ostracoden. Teil 4. Mitteilungen aus den Hamburgischen Zoologischen Museum und Institut, 77: 101-204.

Hartmann, G. 1981. Die Ostracoden der Ordnung Podocopida G. W. Müller, 1894 der subtropisch-tropischen ostküste Australiens (zwischen Eden in süden und Heron-Island im norden). Mitteilungen aus den Hamburgischen Zoologischen Museum und Institut, 78: 97-149.

Hartmann, G. \& Kühl, C. 1978. Zur Variabilität der Oberflàenornamente der Schalen lebender Ostracoden-Populationen. Mitteilungen aus den Hamburgischen Zoologischen Museum und Institut, 73 (1): 83-225.

Holden, J.C. 1964. Upper Cretaceous ostracods from California. Palaeontology, 7: 393-429.

Holden, J.C. 1967. Late Cenozoic ostracods from the drowned terraces in the Hawaiian Islands. Pacific Science, 21 (1): 1-50.

Holden, J.C. 1976. Late Cenozoic Ostracoda from Midway Island Drill Holes. United States Geological Survey Professional Paper, 680: $1-40$

Howe, H.V. 1934. The ostracode genus Cytherelloidea in the Gulf Coast Tertiary. Journal of Paleontology, 8: 29-34.

Howe, H.V. \& Chambers, J. 1935. Louisiana Jackson Eocene Ostracoda. Geological Bulletin, State of Louisiana Department of Conservation, Louisiana Geological Survey, 5: 1-65.

Howe, H.V. \& McKenzie, K.G. 1989. Recent marine Ostracoda (Crustacea) from Darwin and North Western Australia. Northern Territory Museum of Arts and Sciences, Monograph Series, 3: 1-50.

Hughes, G.W. 1977. The Geology and Foraminiferal Micropalaeontology of the Lungga and Itina Basin areas of Western Guadalcanal, Solomon Islands. PhD thesis. University of Wales, Aberystwyth, 401pp.

Ishizaki, K. 1963. Japanese Miocene ostracods from the Sunakosa Member of the Yatsuo Formation, east of Kanazawa City, Ishikawa Prefercture. Japanese Journal of Geology and Geography, 34 (2): $19-34$.

Jain, S.P. 1978. Recent Ostracoda of Mandvi Beach, west coast of India. Bulletin of the Indian Geologists Association, 11: 89-139.

Jellinek, T. 1993. Zur Ökologie und Systematik rezenter Ostracoden aus dem Bereich des kenianischen Barriere-Riffs. Senckenbergiana Lethaea, 73 (1): 83-225.

Kaye, P. 1965. Further Ostracoda from the British Lower Cretaceous. Senckenbergiana Lethaea, 46 (1): 73-81.

Kingma, J.Th. 1948. Contributions to the Knowledge of the Young Caenozoic Ostracoda from the Malayan Region. PhD thesis. University of Utrecht, Utrecht, $119 \mathrm{pp}$.

Krutak, P. 1961. Jackson Eocene Ostracoda from the Cocoa Sand of Alabama. Journal of Paleontology, 35: 769-788.
LeRoy, W. 1940. The ostracode genus Cytherelloidea from the late Tertiary of the Netherlands East Indies. Natuurkundig Tijdschrift voor Nederlandsch-Indië, 100 (4): 179-196.

LeRoy, L.W. 1943. Pleistocene and Pliocene ostracoda of the Coastal Region of Southern California. Journal of Paleontology, 17 (4): $354-373$.

Maddocks, R.F. 1968. Commensal and free living species of Paracypria Müller, 1894 (Ostracoda, Pontocyprididae) from the Indian and Southern Oceans. Crustaceana, 15: 121-136.

Maddocks, R.F. 1969. Recent ostracodes of the Family Pontocyprididae chiefly from the Indian Ocean. Smithsonian Contributions to Zoology, 7: $1-56$.

Maddocks, R.F. 1990. Living and fossil Macrocyprididae (Ostracoda). University of Kansas Paleontological Publications, Monograph, 2: $1-403$.

Malz, H. 1981. Palaeozane Ostracoden von den Emperor Seamounts. N.W.-Pazifik. Zitteliana, 7: 1-54.

McKenzie, K.G. 1967. Recent Ostracoda from Port Phillip Bay, Victoria. Proceedings of the Royal Society of Victoria, 80: 61-106.

Mostafawi, N. 1992. Rezente Ostracoden aus dem mittleren SundaSchelf, zwischen der Malaiischen und Borneo. Senckenbergiana Lethaea, 72: 129-168.

Okubo, I. 1979. Recent marine Ostracoda in the Inland Sea of Japan - 14: two species of Propontocypris. Research Bulletin of Shijitsu Women's College and Okayama Shujitsu Junior College, 9: 143-157.

Sars, G.O. 1866. Oversikt af Norges marine Ostracoder. Forhandlinger I Videnskabs-Selskabet I Christiana: 147-174.

Scott, A. 1905. Report on the Ostracoda collected by Professor Herdman at Ceylon in 1902. Supplementary Report, Ceylon Pearl Oyster Fisheries, 22: 365-384.

Swain, F.M. 1967. Ostracoda from the Gulf of California. Memoirs of the Geological Society of America, 101: 1-139.

Swanson, K.M. 1969. Some Lower Miocene ostracoda from the Middle Waipara District, New Zealand. Transactions of the Royal Society, New Zealand, Earth Sciences, 7 (3): 33-48.

Teeter, J.W. 1975. Distribution of Holocene marine Ostracoda from Belize. In: Wantland, K.F. \& Pusey, W.C. (Eds), Belize Shelf Carbonate Sediments, Clastic Sediments and Ecology. American Association of Petroleum Geologists, Studies in Geology, 2: 400-499.

Titterton, R. 1984. The taxonomy, Ecology and Distribution of Recent Ostracoda from the Solomon Islands. PhD thesis. University of Wales, Aberystwyth, $945 \mathrm{pp}$.

Titterton, R. \& Whatley, R.C. 1988. Recent Bairdiinae (Crustacea, Ostracoda) from the Solomon Islands. Journal of Micropalaeontology, 7 (2): 111-142.

Titterton, R. \& Whatley, R.C. 2005. Recent marine Ostracoda from the Solomon Islands. Part 2: Cytheracea, Xestoleberidae. Revista Española de Micropaleontología, 37: 291-313.

Titterton, R., Whatley, R.C. \& Whittaker, J.E. 2001. A review of some key species of mainly Indo-Pacific Ostracoda from the collections of G. S. Brady. Journal of Micropalaeontology, 20: 111-142.

Triebel, E. von 1960. Die taxonomische stellung und die gattungen der unterfamilie Macrocypridinae (Ostracoda). Senckenbergiana Biologica, 41 (1/2): 109-124.

Veen, J.E. van 1932. Die Cytherellidae der Maastrichter tuffkreide unt des Kunarder Korallenkalkes von Sued-Limburg. Verhandelingen van het Geologisch-Mijnbouwkundig Genootschap voor Nederland en Kolonien, Geologische Serie, 9: 317-364.

Watson, K.A. 1988. The taxonomy and distribution of Recent reef Ostacoda from the Palau Seribu, Java Sea. PhD thesis. University of Wales, Aberystwyth, 434 pp.

Whatley, R.C. \& Downing, S.E. 1983. Middle Miocene Ostracoda from Victoria, Australia. Revista Española de Micropaleontología, 15: 347-407.

Whatley, R.C. \& Keeler, N.P. 1989. Ostracodes actuels de l'Île de la Réunion (Sud-Oeste de l'Océan Indien). Revue de Micropaléontologie, 32: $63-84$

Whatley, R.C. \& Roberts, R. 1995. Marine Ostracoda from Pitcairn, Oeno and Henderson Islands. In: Benton, T. G. \& Spencer, T. (Eds). The Pitcairn Islands: biogeography, ecology and prehistory. Biological Journal of the Linnean Society, 56: 359-364. 
Whatley, R.C. \& Titterton, R. 1981. Some new Recent podocopid Ostracoda from the Solomon Island, South-West Pacific. Revista Española de Micropaleontología, 13 (2): 157-170.

Whatley, R.C. \& Zhao, Q. 1987. The Recent Ostracoda of the Malacca Straits, Part 1. Revista Española de Micropaleontología, 19 (3): 327-366.

Whatley, R.C. \& Zhao, Q. 1988. A revision of Brady's 1869 study of the Ostracoda of Hong Kong. Journal of Micropalaeontology, 7: 21-29.

Whatley, R.C., Cooke, P.C.B. \& Warne, M.T. 1995. The Ostracoda from Lee Point on Shoal Bay, Northern Australia. Part 1 - Cladocopa and Platycopina. Revista Española de Micropaleontología, 27 (3): 69-89.

Whatley, R.C., Cooke, P.C.B. \& Warne, M.T. 1996. The Ostracoda from Lee Point on Shoal Bay, Northern Australia: Part 2 -
Podocopina (Bairdiacea and Cypridacea). Revista Española de Micropaleontología, 28 (1): 5-41.

Whatley, R.C., Jones, R.L. \& Wouters, K. 2000. The Ostracoda of Easter Island. Revista Española de Micropalaéontologia, 32 (1): 79-106.

Yassini, I. \& Jones, B.G. 1995. Foraminifera and Ostracoda from Estuarine and Shelf Environments on the Southern Coast of Australia. The University of Woolagong Press, Woolagong, 484pp.

Yassini, I., Jones, B.G. \& Jones, M.R. 1993. Ostracods from the Gulf of Carpentaria, northeastern Australia. Senckenbergiana Lethaea, 73: 375-406.

Zhao, Q. \& Whatley, R.C. 1989. Recent podocopid Ostracoda of the Sedili River and Jason bay, Southeast Malay Peninsula. Micropaleontology, 35: 168-187. 